\title{
HYDROGEOLOGICAL CONDITIONS FOR THE PRESENCE OF OIL AND GAS IN THE WESTERN SEGMENT OF THE YENISEI-KHATANGA REGIONAL TROUGH
}

\author{
D. A. Novikov1, 2
}

\author{
${ }^{1}$ A.A. Trofimuk Institute of Petroleum Geology and Geophysics, Siberian Branch of RAS, Novosibirsk, Russia \\ ${ }^{2}$ Novosibirsk National Research State University, Novosibirsk, Russia
}

\begin{abstract}
This article describes the petroleum potential of the Mesozoic deposits in the western segment of the Yenisei-Khatanga regional trough, as assessed from the hydrogeological data. The study area includes the Krasnoyarsk region and neighbouring zones of the Yamal-Nenets Autonomous District (Fig. 1). In tectonic terms, it is confined to the Yenisei-Khatanga regional trough and separates the Taimyr system of tectonic dislocations from the Siberian Platform [Kontorovich, 2011; Pronkin et al., 2012]. The Meso-Cenozoic section (up to 6-12 km) [Dolmatova, Peshkova, 2001] is limited by the Malokhet-Rassokhin-Balakhnin deep fault and the same name system of mega-ramparts in the east. In the west, it opens up and merges with the structures of the West Siberian megabasin. The hydrogeological materials collected in the study area for almost 40 years, since 1977, remained unconsolidated, and our study did so for the first time. To date, more than 200 deep wells have been drilled in this area, and more than 25 hydrocarbon fields have been discovered.

Most geologists acknowledge the leading role of water in the processes of formation, migration, accumulation and degradation of hydrocarbons: water is a medium and an active participant in mass transfer. In this regard, the compositions of groundwater, water-soluble gas and organic matter are widely discussed as hydrogeological criteria that may suggest the presence of oil and gas. The hydrogeological criteria for petroleum prospecting have been classified, and it is now possible to take into account the origin and significance of each indicator, integrate their impacts and attempt at forecasting the regional, zonal and local oil and gas fields.

In the Mesozoic section, sodium chloride ground waters predominate. The inversion type of vertical hydrogeochemical zoning is dominant in the study area, and involves the entire complex of deposits: the mineralization decreases from 16-20 g/ $\mathrm{dm}^{3}$ in the Apt-Alb-Senoman complex to $5-10 \mathrm{~g} / \mathrm{dm}^{3}$ or less in the Jurassic aquifers (Fig. 4). The inversion is accompanied by a change in the ion-salt composition of groundwater. The concentration of $\mathrm{HCO}_{3}$ ion increases with depth; the type of groundwater changes from predominantly sodium chloride (at a depth of $\sim 2300 \mathrm{~m}$ ) to chloride-hydrocarbonate sodium and hydrocarbonate-chloride sodium.

Using the hydrogeological data, we assessed the petroleum potential of the sedimentary cover in the western segment of the Yenisei-Khatanga regional trough. Based on the analysis of the set of criteria and their individual contributions to the overall assessment of the prospects, we have identified 16 highly promising and 20 mediumpotential structures that can substantiate further oil-and-gas prospecting, which may discover skipped and new fields. Prospecting can prove highly effective in the Cretaceous reservoirs (Upper Sukhodudinka and Lower Kheta) located in the Nadadyan, Middle Yarov, Tokachin, Turkov, Yarov and other areas (Fig. 6). The Jurassic deposits are promising for small- and medium-sized oil-and-gas reservoirs, as suggested by the geological exploration of previous years, which
\end{abstract}

\section{RESEARCH ARTICLE}

Received: October 26, 2016

Recommended by K.Zh. Seminsky

For citation: Novikov D.A., 2017. Hydrogeological conditions for the presence of oil and gas in the western segment of the Yenisei-Khatanga regional trough. Geodynamics \& Tectonophysics 8 (4), 881-901. doi:10.5800/GT-2017-8-4-0322.

Для цитирования: Новиков Д.А. Гидрогеологические предпосылки нефтегазоносности западной части Енисей-Хатангского регионального прогиба // Геодинамика и тектонофизика. 2017. T. 8. № 4. C. 881-901. doi:10.5800/GT-2017-8-4-0322. 
discovered the Zima (1966) and Khabei (1982) fields. According to the proposed set of the hydrogeological criteria, the most promising among the Jurassic reservoirs is the Malyshev reservoir in the Deryabin, Pelyatkin, Middle Yarov, Tampei and Turkov areas. Promising to a lesser extent are the Sigov (Rassokhin and Sukhodudinka areas) and Nadoyakh (Sukhodudinka area) reservoirs.

Key words: hydrogeological criteria of oil- and gas-bearing capacities; petroleum potential; groundwater; type of hydrogeological section; hydrogeochemical inversion

\title{
ГИДРОГЕОЛОГИЧЕСКИЕ ПРЕДПОСЫЛКИ НЕФТЕГАЗОНОСНОСТИ ЗАПАДНОЙ ЧАСТИ ЕНИСЕЙ-ХАТАНГСКОГО РЕГИОНАЛЬНОГО ПРОГИБА
}

\author{
Д. А. Новиков ${ }^{1,2}$ \\ ${ }^{1}$ Институт нефтегазовой геологии и геофизики им. А.А. Трофимука СО РАН, Новосибирск, Россия \\ ${ }^{2}$ Новосибирский национальный исследовательский государственный университет, \\ Новосибирск, Россия
}

\begin{abstract}
Аннотация: Приводятся результаты оценки перспектив нефтегазоносности мезозойских отложений западной части Енисей-Хатангского регионального прогиба по гидрогеологическим данным. Большинством геологов признается ведущая роль воды в процессах образования, миграции, аккумуляции и деградации углеводородов (УВ), в которых она выступает как среда и активный участник массопереноса. В этой связи характеристики состава подземных вод, водорастворенного газа (ВРГ) и органического вещества (ОВ) нашли широкое применение в качестве гидрогеологических критериев нефтегазоносности. Сегодня можно говорить о классификационной системе нефтегазопоисковых гидрогеологических критериев, учитывающих характер и значение каждого показателя, с возможностями их комплексирования и применения на этапе регионального, зонального и локального прогноза. Исследуемая территория находится в пределах Красноярского края и сопредельных районов Ямало-Ненецкого автономного округа (рис. 1). В тектоническом отношении она приурочена к Енисей-Хатангскому региональному прогибу (ЕХРП) и отделяет Таймырскую систему дислокаций от Сибирской платформы [Kontorovich, 2011; Pronkin et al., 2012]. Мезокайнозойская часть разреза (до 6-12 км) [Dolmatova, Peshkova, 2001] в восточном направлении ограничена Малохетско-Рассохинско-Балахнинским глубинным разломом с системой одноименных мегавалов, на западе - открывается и сливается со структурами Западно-Сибирского мегабассейна (ЗСМБ). По изучаемому региону почти 40 лет (с 1977 г.) не проводилось обобщения гидрогеологических материалов, что и выполнено в работе впервые. К настоящему времени здесь пробурено более 200 глубоких скважин и открыто более 25 месторождений углеводородов.

В пределах мезозойского разреза преобладают подземные воды хлоридного натриевого типа. На исследуемой территории выявлено доминирование инверсионного типа вертикальной гидрогеохимической зональности, охватывающего весь комплекс отложений, - происходит уменьшение минерализации от 16-20 г/дм в апт-альб-сеноманском комплексе до 5-10 г/дм³ и менее в водоносных горизонтах юрского возраста (рис. 4). Инверсия сопровождается сменой ионно-солевого состава подземных вод. С глубиной увеличиваются концентрации $\mathrm{HCO}_{3}$-иона, происходит переход от преимущественно хлоридного натриевого (на глубинах $\sim 2300$ м) к хлоридно-гидрокарбонатному натриевому и гидрокарбонатно-хлоридному натриевому типу вод.

Выполнена оценка перспектив нефтегазоносности осадочного чехла западной части Енисей-Хатангского регионального прогиба по гидрогеологическим данным. Анализ комплекса критериев и их индивидуального вклада в общую оценку перспективности объектов выявил 16 высокоперспективных и 20 структур со средними перспективами для обоснования дальнейших нефтегазопоисковых работ на обнаружение пропущенных залежей и открытие новых месторождений. Высокую результативность поисковых работ следует связывать с меловыми резервуарами (верхнесуходудинский и нижнехетский) на Нанадянской, Средне-Яровской, Токачинской, Турковской, Яровской и других площадях (рис. 6). В юрских отложениях следует ожидать открытия мелких и средних по запасам залежей, что подтверждается результатами геологоразведочных работ прошлых лет - открытиями Зимнего (1966) и Хабейского (1982) месторождений. По предложенному комплексу гидрогеологических критериев среди юрских резервуаров наиболее перспективным является малышевский резервуар на Дерябинской, Пеляткинской, Средне-Яровской, Тампейской, Турковской площадях, в меньшей степени - сиговский (Рассохинская и Суходудинская площади) и надояхский (Суходудинская площадь) резервуары.
\end{abstract}

Ключевые слова: гидрогеологические критерии нефтегазоносности; подземные воды; тип гидрогеологического разреза; гидрогеохимическая инверсия 


\section{1. ВВЕДЕНИЕ}

До настоящего времени природа Енисей-Хатангского регионального прогиба (ЕХРП) носит дискуссионный характер. Мы придерживаемся точки зрения Н.Л. Добрецова с соавторами о том, что ЕХРП с одноименным рифтом в основании относится к пермско-триасово-юрскому времени, с рифтовой стадией и максимальной скоростью осадконакопления в конце перми - раннем-среднем триасе (260230 млн лет) [Dobretsov et al., 2013], а турон-кайнозойский этап тектонического развития оказал основное влияние на формирование и распределение месторождений нефти и газа в его пределах [Kontorovich, 2011]. Все это во многом определило эволюцию Енисей-Хатангского осадочного бассейна, историю его тектонического развития и сформировало современную структуру водонапорной системы с характерными чертами геотермического, гидродинамического и гидрогеохимического поля.

Согласно нефтегазогеологическому районированию, регион расположен в северной части ЛеноТунгусской нефтегазоносной провинции (НГП) и выделяется в составе одноименной нефтегазоносной области (НГО). На западе он граничит с Гыданской НГО, входящей в состав Западно-Сибирской НГП [Kontorovich et al., 1994; Kontorovich, 2011; Stoupakova et al., 2013]. В гидрогеологическом отношении исследуемый район входит в состав Восточно-Сибирской артезианской области [Baskov et al., 1974].

Вопрос о нефтегазоносности исследуемой территории впервые был поставлен Н.А. Гедройцем в 1935 г. после проведения маршрутных геологических исследований в Усть-Енисейском районе и открытия выходов горючих газов и озер с минерализованными водами [Ginsburg, Afanasov, 1971]. Изучение гидрогеологических и гидрогеохимических особенностей западной части ЕХРП связано с именами Е.Г.Бро, Г.Д. Гинсбурга, Г.А. Ивановой, Н.И. Обидина, В.М. Пономарева, Г.Е. Рябухина, П.Д. Сиденко, .В. Федорова, А.В. Щербакова и многих других [Ginsburg et al., 1969; Ginsburg, Ivanova, 1971, 1977; Ivanova, 1973; Ivanova, Mel'kanovitskaya, 1973; Ravdonikas, 1962; Rostovtsev, Ravdonikas, 1958]. Следует отметить, что по изучаемому региону почти 40 лет (с 1977 г.) не проводилось обобщения гидрогеологических материалов, что и выполнено в работе впервые. К настоящему времени здесь пробурено более 200 глубоких скважин и открыто более 25 месторождений углеводородов [Borodkin, Kurchikov, 2015; Golovin, 2009; Isayev et al., 2010; Kontorovich, Ershov, 2010; Kurchikov, Borodkin, 2015; Polyakov et al., 2012] (рис. 1). Степень изученности гидрогеологических условий, гидрогеотермии, гидродинамики, гидрогеохимии и мерзлотных условий неравномерна по площади и геологическому разрезу.

\section{2. РЕЗУЛЬТАТЫ ИССЛЕДОВАНИЙ И ОБСУЖДЕНИЕ}

В мезокайнозойской части разреза во многом повторяются особенности геологического строения прилегающих районов ЗСМБ. В этой связи за основу гидрогеологического расчленения мезокайнозойских отложений изучаемой части ЕХРП были взяты принципы гидрогеологической стратификации прилегающих районов Западной Сибири [Nudner, 1970; Zaitsev, 1972; Kartsev et al., 1986; Kruglikov et al., 1985; Matusevich et al., 2005; Rozin, 1977; Torgovanova et al., 1960]. В пределах нижнего (мезозойского) гидрогеологического этажа выделяют пять водоносных комплексов (сверху вниз): аптальб-сеноманский, неокомский, верхнеюрский, нижнесреднеюрский и триас-палеозойский. От зоны активного водообмена вышеперечисленные комплексы изолированы выдержанным по простиранию турон-олигоценовым водоупором, экранирующие способности которого нарушаются в прибортовых частях ЗСМБ при литологическом замещении на песчаные разности. На исследуемой территории установлены все комплексы. При этом распространение и выдержанность отдельных водоносных горизонтов и водоупоров неодинаковы.

Выявлена сложная гидрогеологическая структура бассейна, обусловленная размывом водоупорных и водопроницаемых толщ и дизъюнктивной тектоникой. По полноте разреза выделено восемь типов гидрогеологических структур, распространение которых с учетом тектонических и литологических факторов показано на рисунке 2 [Kokh, Novikov, 2014; Novikov, 2013, 2014]. Ниже приводится их описание. Первый тип гидрогеологического разреза характеризуется наличием всех водоносных горизонтов и водоупоров от нижней юры до верхнего мела. Особенность второго типа - глинизация верхнеюрского водоносного комплекса. Третий тип характеризуется глинизацией нижнехетского и нижнехетско-суходудинского резервуаров неокомского комплекса. В четвертом установлены размывы пород всех четырех гидрогеологических комплексов. Для пятого типа установлен частичный или полный размыв отложений верхнеюрского комплекса. В шестом типе, в отличие от пятого, из разреза выпадают нижнехетский и нижнехетско-суходудинский резервуары нижней части неокомского комплекса. В седьмом типе отсутствует нижняя часть нижнесреднеюрского комплекса и, как во втором и третьем, заглинизирован верхнеюрский и низы неокомского комплекса. Восьмой тип гидрогеологического разреза характеризуется 

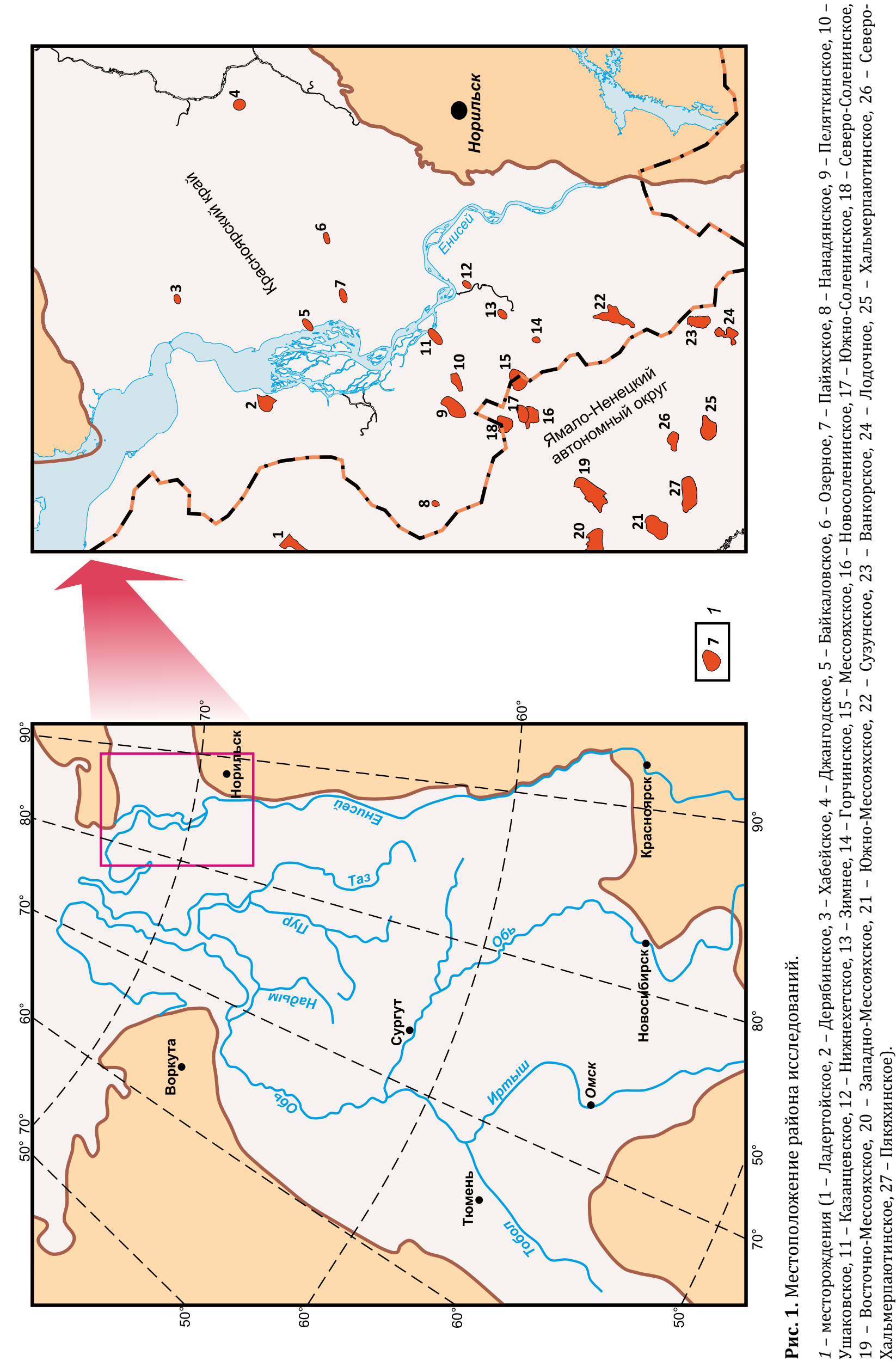

$\stackrel{m}{\sim}$

过

苛

전

ำ

岕迹

ฟี

(1)

$\exists \vec{n}$

定定

离

$1 \sum^{\infty}$

है

要 1

बㅇำ

át

芩

त्ञ

茎苟

$\infty 1$

馬

苋.

in

进约

落

染

+ वे व्ँ

年

웡

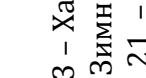

बे

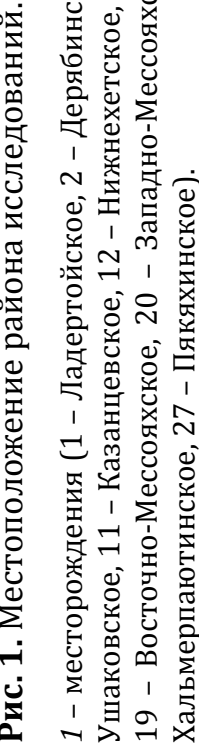

人

s 동

N

$\int_{0}^{1} \underset{0}{1}$

론

完产

西

$1 \overline{0}$

टे 1 है

总군

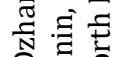

$1 \div 2$

*

준

10

هั

क $\widetilde{0}$

할

is $N$

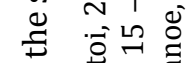

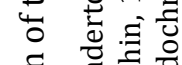

ฮี

चू

웜

อ 1 造 


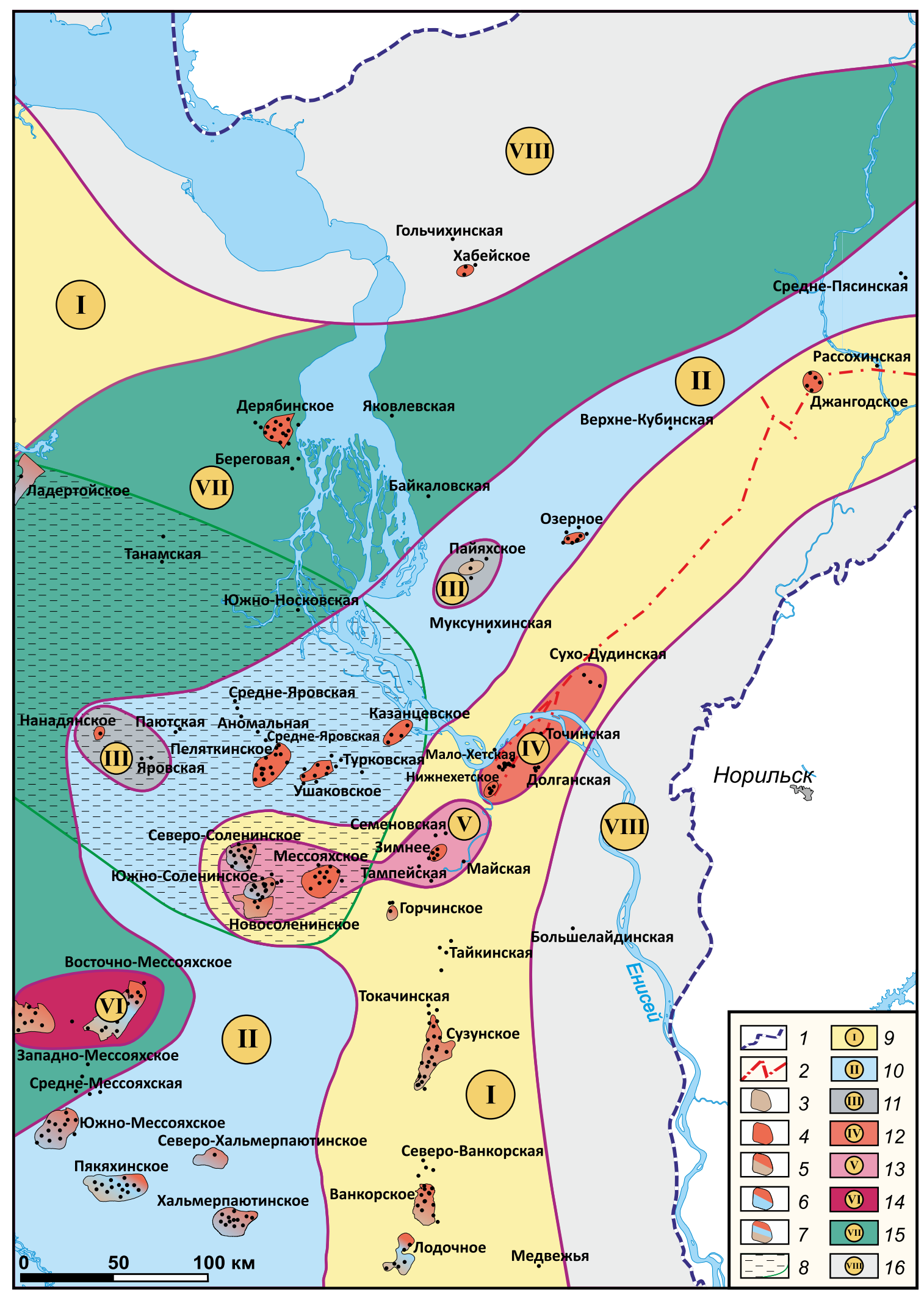

Рис. 2. Карта гидрогеологического районирования западной части Енисей-Хатангского регионального прогиба.

1 - граница распространения мезозойско-кайнозойского осадочного чехла; 2 - разломы; 3-7 - месторождения: 3 - нефтяные, 4 газовые, 5 - газонефтяные, 6 - газоконденсатные, 7 - нефтегазоконденсатные; 8 - зона АВПд; 9-16 - тип гидрогеологического разреза: 9 - первый, 10 - второй, 11 - третий, 12 - четвертый, 13 - пятый, 14 - шестой, 15 - седьмой, 16 - восьмой.

Fig. 2. Hydrogeological zoning of the western segment of the Yenisei-Khatanga regional trough.

1 - boundary of the Mesozoic-Cenozoic sedimentary cover; 2 - faults; 3-7 - fields: 3 - oil, 4 - gas, 5 - gas-and-oil, 6 - gas condensate, 7 oil-and-gas condensate; 8 - zone of anomalously high formation pressure; 9-16 - types of hydrogeological section: 9 - first, 10 - second, 11 - third, 12 - fourth, 13 - fifth, 14 - sixth, 15 - seventh, 16 - eighth. 
минимальной мощностью осадочного чехла и отсутствием в разрезе юрских отложений.

Влияние типа гидрогеологической структуры на гидродинамический режим и вертикальную гидрогеохимическую зональность является определяющим. Изменение минерализации пластовых вод по латерали и разрезу имеет зональный характер (таблица). Рассмотрим подробнее выявленные закономерности.

Первый тип структуры приурочен к восточному борту ЕХРП и осложнен Малохетско-БалахнинскоРассохинским глубинным разломом, в зоне которого наблюдается разгрузка подземных вод, совпадающая с зоной повышенных геотермических градиентов (до $3.3{ }^{\circ} \mathrm{C} / 100$ м) (рис. 2). Разрез характеризуется гидростатическими пластовыми давлениями. Величина общей минерализации подземных вод снижается с глубиной с 17 до 2-3 г/дм ${ }^{3}$. Состав пластовых вод - преимущественно хлоридный натриевый и гидрокарбонатно-хлоридный натриевый (по классификации С.А. Щукарева) (таблица, рис. 3). В целом здесь - на Лодочной, Рассохинской и Сузунской площадях - доминирует инверсионный тип вертикальной гидрогеохимической зональности и более сложный - на СевероВанкорской и Токачинской площадях (рис. 4), что было установлено ранее для некоторых площадей изучаемого региона [Bro et al., 1973; Bro, 1977; Ginsburg et al., 1969; Ginsburg, Ivanova, 1971, 1977; Ravdonikas, 1962].

Второй тип гидрогеологического разреза развит в северных и западных районах изучаемого региона и в гидродинамическом плане характеризуется повышенными и аномально высокими пластовыми давлениями (АВПД) в пределах неокомского и нижнесреднеюрского комплекса в центральной части исследуемой территории (см. рис. 2). Максимальные значения пластовых давлений установлены на Турковской площади (более 55 МПа в интервале глубин 3300-3450 м). Уменьшение минерализации с глубиной выявлено на Казанцевской, Пеляткинской, Средне-Яровской, Турковской, Ушаковской и Южно-Мессояхской площадях.

Здесь величина общей минерализации не превышает 16 г/дм³ при закономерном уменьшении с глубиной (например, на Пеляткинской площади до 2.8 г/дм ${ }^{3}$ на глубине 2655 м). По составу преобладают хлоридные натриевые и хлоридно-гидрокарбонатные натриевые воды. С глубиной происходит увеличение содержания гидрокарбонат-иона (по мере приближения к заглинизированным отложениям верхней юры).

В гидродинамическом отношении гидрогеологические разрезы третьего и четвертого типа характеризуются пластовыми давлениями, близкими к гидростатическим.
Разрез третьего типа развит локально на Нанадянской, Пайяхской и Яровской площадях. Минерализация подземных вод здесь варьируется от 2.2 до 9.0 г/дм ${ }^{3}$ при среднем значении в меловой части разреза 5.4 г/дм³ ${ }^{3}$ На Пайяхской и Яровской площадях выявлен инверсионный тип вертикальной гидрогеохимической зональности с закономерной сменой с глубиной горизонтов вод хлоридного натриевого типа преимущественно хлоридно-гидрокарбонатными и гидрокарбонатными натриевыми (таблица).

Четвертый тип гидрогеологического разреза установлен на Точинской, Долганской, Нижнехетской и Малохетской площадях; последние три характеризуются нормальной гидрогеохимической зональностью, в основном доминируют подземные воды с общей минерализацией 4.0-12.5 г/дм³. Воды имеют хлоридный натриевый состав. Помимо частичного размыва меловых и юрских комплексов, этот тип разреза осложнен зонами деструкции и дизъюнктивными нарушениями. Дизъюнктивная тектоника здесь способствует отепляющему воздействию разгружающихся подземных вод, что приводит к геотермическим аномалиям (геотермические градиенты достигают 3.3-3.7 ${ }^{\circ} \mathrm{C} / 100$ м).

В пятом типе гидрогеологического разреза, в отличие от четвертого, отсутствует размыв верхней части неокомского и апт-альб-сеноманского гидрогеологических комплексов. В пределах нижнесреднеюрского комплекса на Мессояхской площади и в группе Соленинских площадей установлены повышенные и аномально высокие пластовые давления с величиной Ка до 1.2. Общая минерализация варьируется в пределах 1.0-15.5 г/дм³ , с глубиной происходит смена ионно-солевого состава от хлоридно-натриевого до хлоридно-гидрокарбонатного и гидрокарбонатно-хлоридного натриевого (таблица). Инверсионный тип гидрогеохимической зональности установлен на Зимней, Мессояхской, Северо- и Южно-Соленинской площадях (рис. 4).

Шестой тип распространен локально на Восточно- и Западно-Мессояхской площадях. В отличие от пятого типа разреза, здесь отсутствует верхнеюрский гидрогеологический комплекс и нижняя часть неокомского. Разрез характеризуется гидростатическими пластовыми давлениями и средними геотермическими градиентами $2.7{ }^{\circ} \mathrm{C} / 100$ м (рис. 3,4$)$. Подземные воды характеризуются закономерным уменьшением с глубиной общей минерализации (от 7.1 до 3.8 г/дм³) и сменой хлоридного натриевого типа подземных вод на хлоридно-гидрокарбонатный натриевый. Максимальные концентрации $\mathrm{HCO}_{3}$-иона установлены в надояхском резервуape нижнесреднеюрского комплекса и в нижнемалохетском резервуаре неокомского комплекса. 


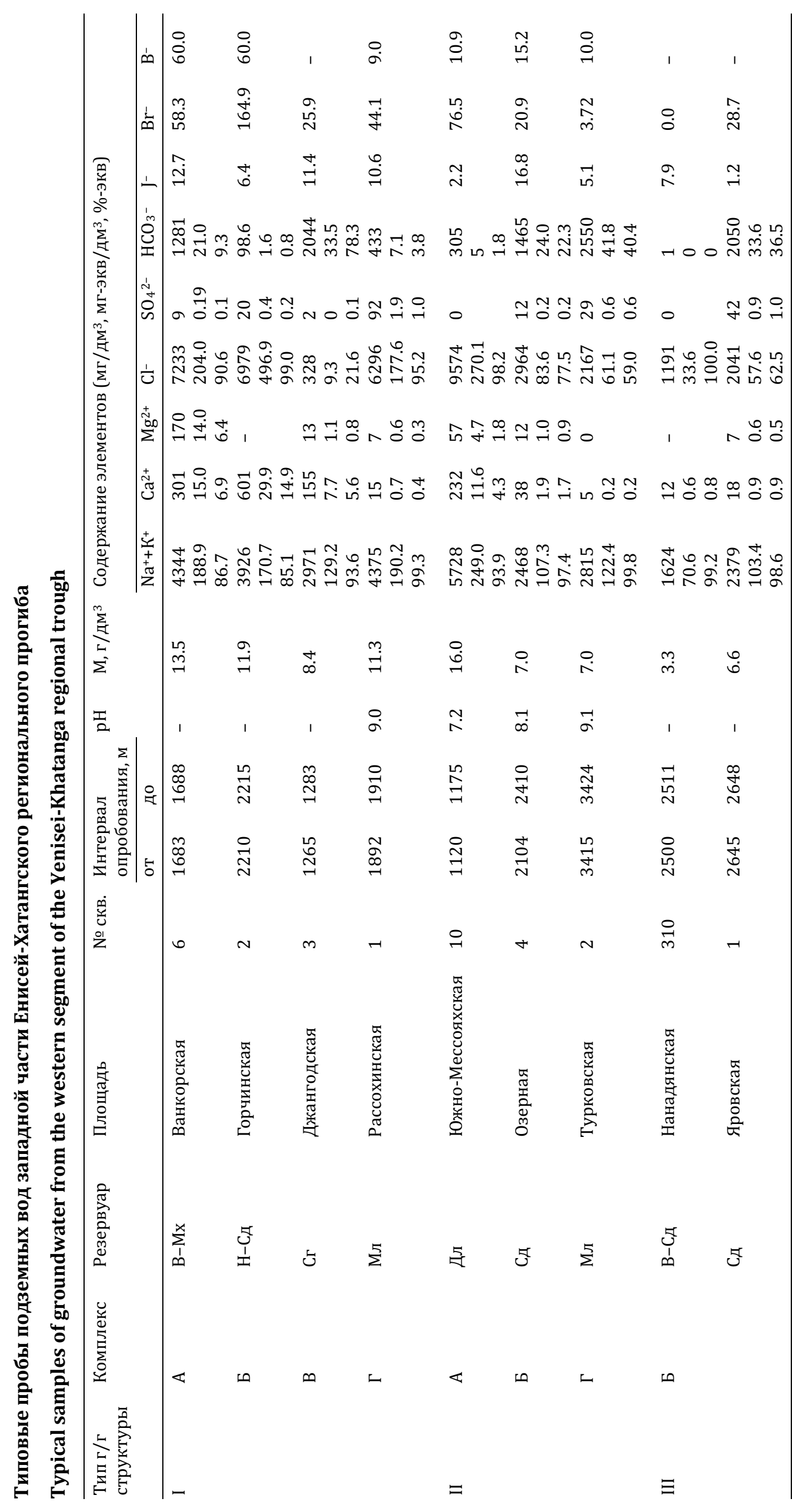




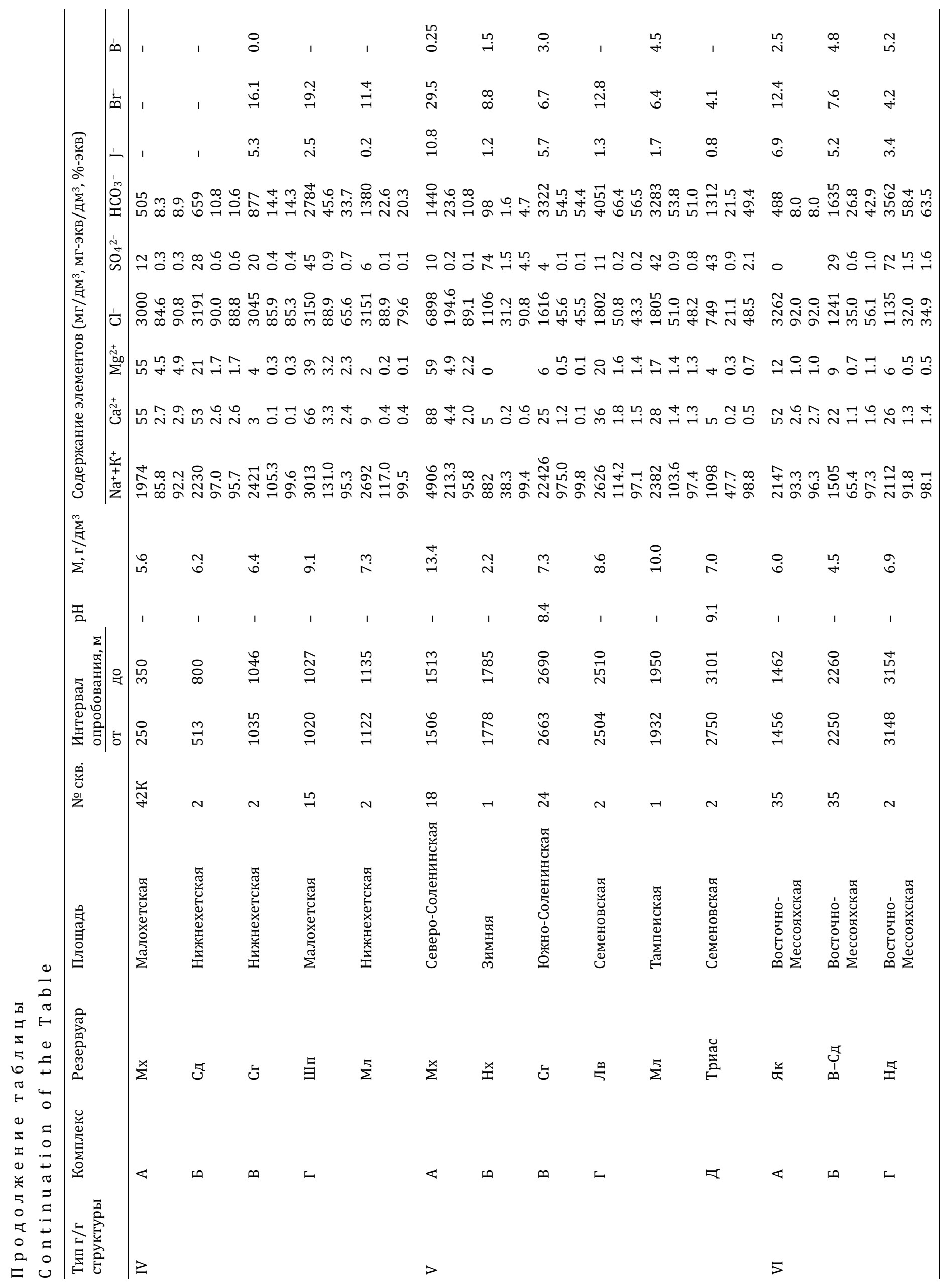




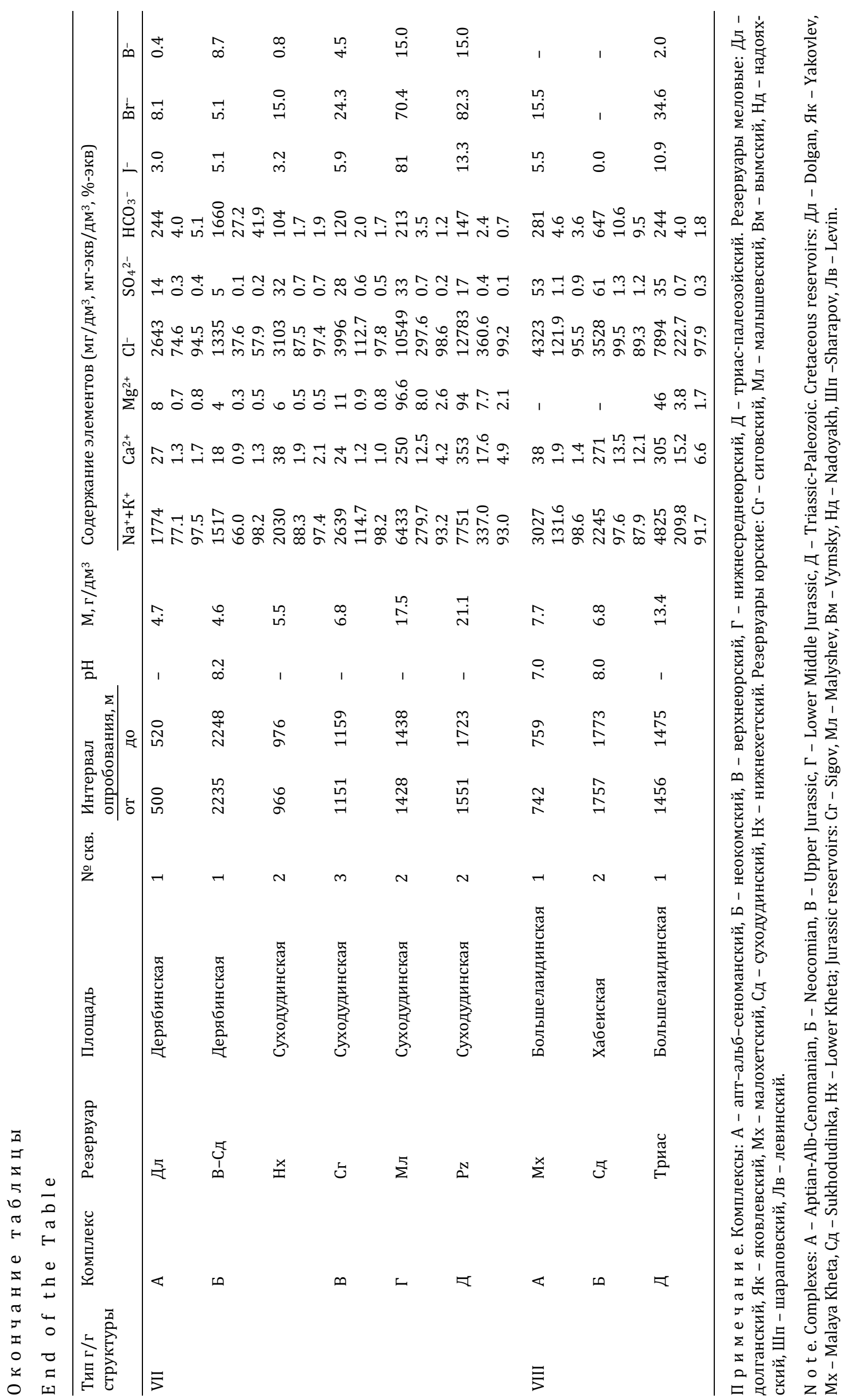


D.A. Novikov: Hydrogeological conditions for the presence of oil and gas...

\begin{tabular}{|c|c|c|c|c|c|c|c|c|}
\hline & \multicolumn{8}{|c|}{ Тип гидрогеологической структуры } \\
\hline & $\mathbf{I}$ & II & III & IV & $\mathbf{V}$ & VI & VII & VIII \\
\hline Комплекс & \multicolumn{8}{|c|}{ Апт-альб-сеноманский } \\
\hline \multicolumn{9}{|l|}{ Резервуар } \\
\hline Мощность, м & $571-840$ & $636-972$ & $774-827$ & $8-380$ & $645-983$ & $673-833$ & $285-913$ & $430-614$ \\
\hline $\mathrm{T},{ }^{\circ} \mathrm{C}$ & $0-40$ & $5-55$ & $15-35$ & $0-5$ & $0-40$ & $10-40$ & $0-65$ & $0-25$ \\
\hline$\Gamma_{\text {сред }},{ }^{\circ} \mathrm{C} / 100 \mathrm{M}$ & 2.6 & 2.8 & 2.8 & 3.3 & 2.9 & 2.7 & 2.8 & 2.2 \\
\hline Ка, д.е. & $0.85-1.00$ & $0.95-1.10$ & $0.95-1.05$ & $0.95-1.05$ & $0.95-1.05$ & $0.95-1.05$ & $1.00-1.05$ & $0.95-1.05$ \\
\hline М, г/дм ${ }^{3}$ & $(10.3-17) / 13.6$ & $(0.4-23.3) / 6.3$ & * & 5.6 & $(11-16.4) / 12.9$ & $(6-7.1) / 6.7$ & $(4.7-15.5) / 12.2$ & * \\
\hline Состав вод & $\mathrm{Cl}-\mathrm{Na}$ & $\begin{array}{c}\mathrm{Cl}-\mathrm{Na} \\
\mathrm{Cl}-\mathrm{HCO}_{3}-\mathrm{Na} \\
\end{array}$ & * & $\mathrm{Cl}-\mathrm{Na}$ & $\mathrm{Cl}-\mathrm{Na}$ & $\mathrm{Cl}-\mathrm{Na}$ & $\begin{array}{c}\mathrm{Cl}-\mathrm{Na} \\
\mathrm{Cl}-\mathrm{HCO}_{3}-\mathrm{Na} \\
\end{array}$ & * \\
\hline Кол-во проб & 3 & 23 & * & 1 & 4 & 4 & 12 & * \\
\hline
\end{tabular}

\begin{tabular}{|c|c|c|c|c|c|c|c|c|}
\hline Комплекс & \multicolumn{8}{|c|}{ Неокомский } \\
\hline & & & & & & & & \\
\hline \multicolumn{9}{|l|}{ Резервуар } \\
\hline & & & $\Rightarrow$ & & & & & \\
\hline & & & & & & 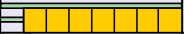 & & \\
\hline Мощность, м & 999-2025 & $1021-2012$ & $1346-1869$ & 489-701 & $610-1228$ & $920-940$ & $1023-2408$ & $601-1100$ \\
\hline $\mathrm{T},{ }^{\circ} \mathrm{C}$ & 5-80 & $25-95$ & $25-90$ & $0-30$ & $5-70$ & $35-80$ & $10-100$ & $0-50$ \\
\hline$\Gamma_{\text {cpen, }},{ }^{\circ} \mathrm{C} / 100 \mathrm{M}$ & 2.6 & 2.8 & 2.8 & 3.3 & 2.9 & 2.7 & 2.8 & 2.2 \\
\hline Ка, д.е. & $0.95-1.05$ & $0.95-1.80$ & $0.85-1.55$ & $0.80-0.95$ & $0.80-1.05$ & $0.85-0.95$ & $0.95-1.25$ & $0.95-1.05$ \\
\hline M, г/дм³ & $(3.8-13.1) / 8.2$ & $(1.0-11.7) / 4.9$ & $(2.2-11.0) / 6.3$ & \begin{tabular}{|c|}
$(4.2-12.0) / 9.3$ \\
\end{tabular} & $(1.3-11.5) / 4.1$ & $(3.5-10.5) / 6.6$ & $(2.1-9.2) / 5.7$ & $(7.0-10.0) / 8.65$ \\
\hline Состав вод & $\mathrm{Cl}-\mathrm{Na}$ & $\begin{array}{c}\mathrm{Cl}-\mathrm{Na}, \\
\mathrm{Cl}-\mathrm{HCO}{ }_{3}-\mathrm{Na}\end{array}$ & $\begin{array}{c}\mathrm{Cl}-\mathrm{HCO}{ }_{3}-\mathrm{Na}, \\
\mathrm{Cl}-\mathrm{Na}\end{array}$ & $\mathrm{Cl}-\mathrm{Na}$ & $\begin{array}{c}\mathrm{Cl}-\mathrm{HCO}_{3}-\mathrm{Na}, \\
\mathrm{Cl}-\mathrm{Na}\end{array}$ & $\begin{array}{c}\mathrm{Cl}-\mathrm{HCO}{ }_{3}-\mathrm{Na} \\
\mathrm{Cl}-\mathrm{Na}\end{array}$ & $\begin{array}{c}\mathrm{Cl}-\mathrm{HCO}{ }_{3}-\mathrm{Na}, \\
\mathrm{Cl}-\mathrm{Na}\end{array}$ & $\mathrm{Cl}-\mathrm{Na}$ \\
\hline Кол-во проб & 32 & 83 & 7 & 23 & 29 & 12 & 27 & 10 \\
\hline
\end{tabular}

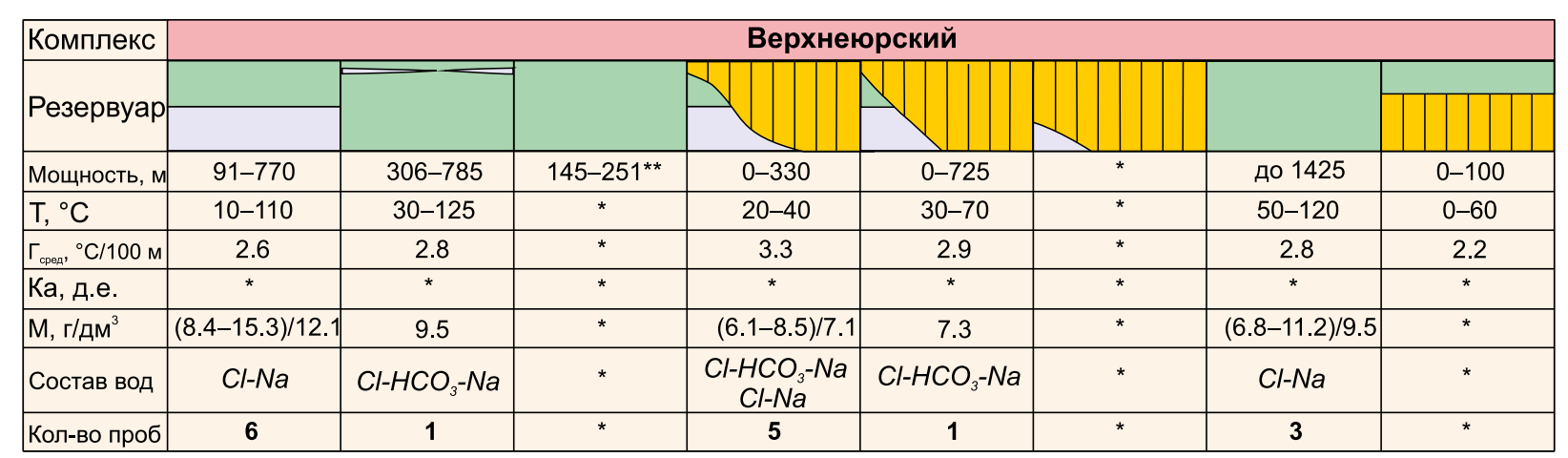

\begin{tabular}{|c|c|c|c|c|c|c|c|c|}
\hline Комплекс & & & & Нижне-сред & неюрский & & & \\
\hline & & & & \begin{tabular}{l|l|l|l|} 
& & &
\end{tabular} & 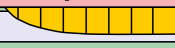 & & & \\
\hline Резервуар & & & & & & & & \\
\hline гезервуар & & & & & & & & \\
\hline & & & & 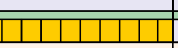 & & & & \\
\hline Мощность, м & $209-1463$ & $530-1880$ & $534^{* *}$ & $208-1558^{* *}$ & $55-1410^{\star \star}$ & $209-558^{* *}$ & $250-600^{* *}$ & 0 \\
\hline $\mathrm{T},{ }^{\circ} \mathrm{C}$ & $30-200$ & $70-300$ & $80-180$ & $20-60$ & $40-180$ & 60-200 & $70-300$ & $0-80$ \\
\hline$\Gamma_{\text {cpen, }}{ }^{\circ} \mathrm{C} / 100 \mathrm{M}$ & 2.6 & 2.8 & 2.8 & 3.3 & 2.9 & 2.7 & 2.8 & 2.2 \\
\hline Ка, д.е. & $0.95-1.05$ & $0.95-1.64$ & $0.85-1.55$ & $1.00-1.05$ & $0.95-1.10$ & $1.00-1.10$ & $0.95-1.50$ & $0.95-1.05$ \\
\hline M, г/дм ${ }^{3}$ & $(11.3-14.0) / 12.6$ & $(3.0-10.0) / 7.5$ & * & $(6.4-10.6) / 8.6$ & $(5.7-12.0) / 8.4$ & 6.9 & $(7.3-7.5) / 7.4$ & * \\
\hline Состав вод & $\mathrm{Cl}-\mathrm{Na}$ & $\mathrm{Cl}-\mathrm{HCO}_{3}-\mathrm{Na}$ & * & $\begin{array}{c}\mathrm{Cl}-\mathrm{HCO}{ }_{3}-\mathrm{Na} \\
\mathrm{Cl}-\mathrm{Na}\end{array}$ & $\mathrm{Cl}-\mathrm{HCO}_{3}-\mathrm{Na}$ & $\mathrm{HCO}_{3}-\mathrm{Cl}-\mathrm{Na}$ & $\mathrm{HCO}_{3}-\mathrm{Cl}-\mathrm{Na}$ & * \\
\hline Кол-во проб & 2 & 5 & * & 10 & 13 & 1 & 2 & * \\
\hline
\end{tabular}

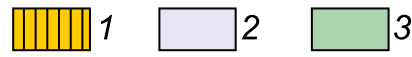

Рис. 3. Гидрогеологическая характеристика типов разрезов западной части Енисей-Хатангского регионального прогиба. 1 - отсутствие отложений; 2 - водоносный горизонт; 3 - водоупор. * - недостаточно данных; ${ }^{* *}$ - вскрытый бурением разрез.

Fig. 3. Hydrogeological characteristics of the types of sections in the western segment of the Yenisei-Khatanga regional trough. 1 - no deposits; 2 - aquifer; 3 - aquitard. ${ }^{*}$ - insufficient data; ${ }^{* *}$ - drilled section. 

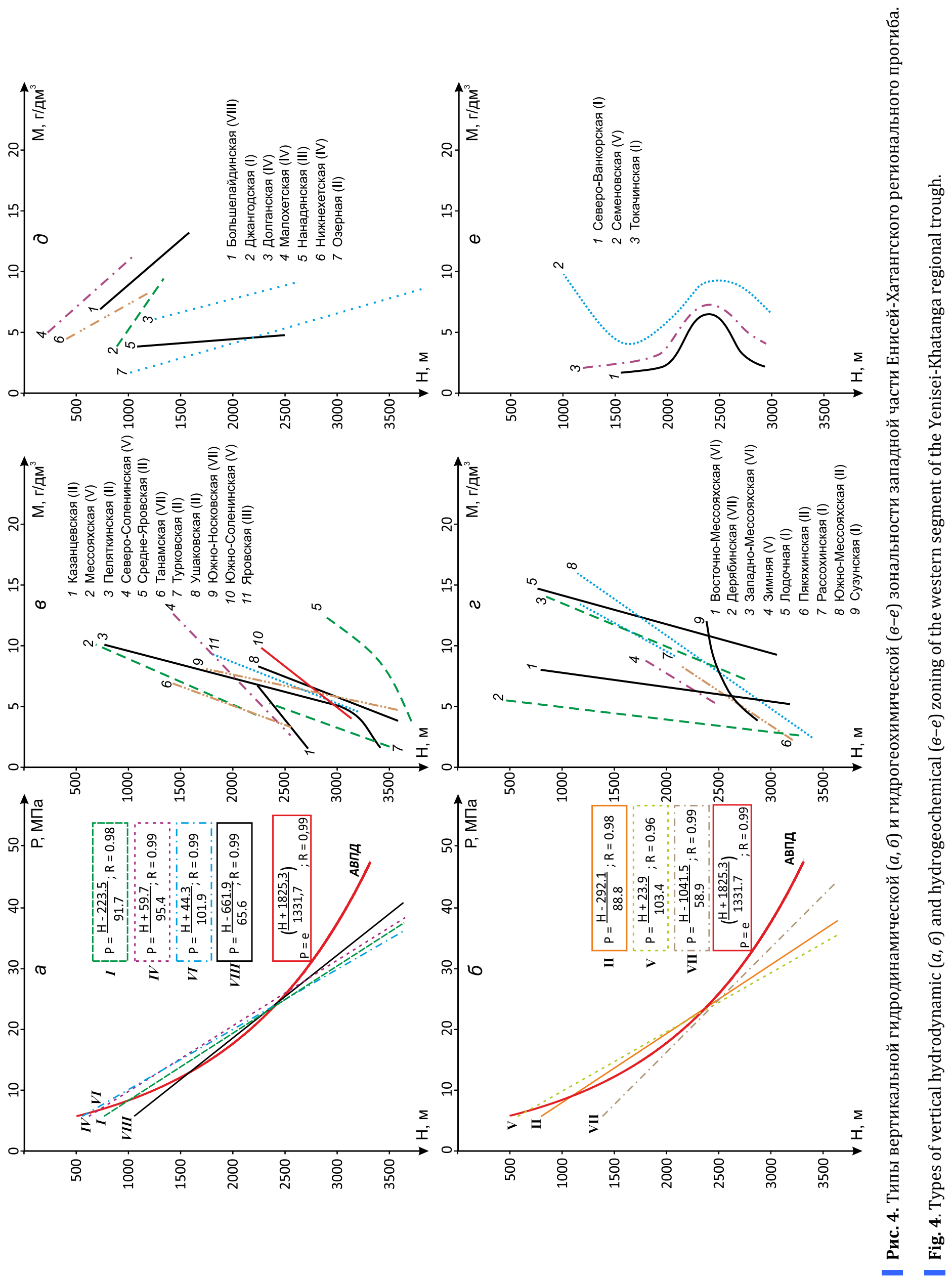
В первом случае его концентрации достигают 3.5 г/дм ${ }^{3}$ (скв. 2 Восточно-Мессояхской площади, интервал испытания 3148-3154 м), во втором 3.9 г/дм ${ }^{3}$ (скв. 33 Восточно-Мессояхской площади, интервал испытания 1977-1988 м). По составу подземные воды - гидрокарбонатно-хлоридные натриевые (таблица).

Седьмой тип разреза широко развит на исследуемой территории и простирается полосой с северовостока на юго-запад. Его главная особенность глинизация нижней части неокомских отложений (верхнесуходудинский, нижнесуходудинский, нижнехетско-суходудинский и нижнехетский), а также полностью - верхнеюрского и частично нижнесреднеюрского гидрогеологического комплекса (малышевский резервуар). Так, мощность глинистой толщи, включающей ачимовскую толщу и гольчихинскую свиту, достигает 420 м на Яковлевской площади и 700 м на Дерябинской площади, что привело к формированию обширной области развития АВПД. Как показывают фактические данные, АВПД установлены в резервуарах нижней части неокома (нижнехетско-суходудинский и нижнехетский) и в малышевском резервуаре нижнесреднеюрского гидрогеологического комплекса на Ладертойской, Пеляткинской, Средне-Яровской, Танамской, Турковской и Южно-Носковской площадях (см. рис. 3,4$)$. С глубиной общая минерализация подземных вод снижается с 14 до 2 г/дм ${ }^{3}$ и происходит смена хлоридного натриевого типа подземных вод на хлоридно-гидрокарбонатный натриевый. По имеющимся данным, инверсионный тип вертикальной гидрогеохимической зональности выявлен на Дерябинской и Западно-Мессояхской площадях.

Восьмой тип с наименьшей мощностью осадочного чехла и отсутствием в разрезе юрских отложений приурочен к прибортовым частям ЕХРП (Большелайдинская, Гольчихинская, Хабейская площади). Особое влияние на его геотермические условия оказывает толща многолетнемерзлых пород (ММП) [Baulin et al., 1967; Grechishchev et al., 1983; Ravdonikas, 1962; Rosenbaum, Shpolyanskaya, 2000; Trofimov, Vasil'chuk, 1987], местами достигающая 600 м, за исключением русла р. Енисея, где выявлены многочисленные талики. Гидродинамическое поле характеризуется гидростатическими пластовыми давлениями. По составу воды - хлоридно-натриевые с общей минерализацией от 5 до 14 г/дм³ (рис. 4).

Таким образом, как показали проведенные исследования, современная гидрогеологическая структура западной части ЕХРП весьма сложна и формировалась на протяжении длительной геологической истории. Установлены восемь типов гидрогеологического разреза и границы между ними.
На настоящем этапе развития водонапорной толщи западной части ЕХРП и сопредельных территорий мощная криогенная толща, наравне с региональным турон-олигоценовым водоупором, выступает дополнительным экраном и надежно защищает меловые и юрские нефтегазоносные комплексы от промыва инфильтрационными водами.

Вследствие высокой степени гидрогеологической закрытости недр, процессов элизионного водообмена при уплотнении глинистых толщ сформировались гидрогеохимические и гидродинамические условия, типичные для элизионной литостатической водонапорной системы, - инверсионный тип вертикальной гидрогеохимической зональности, повышенные начальные пластовые давления [Matusevich et al., 2005]. В гидродинамическом плане это проявляется в повышенных и аномально высоких пластовых давлениях в низах неокомского и в пределах малышевского резервуара нижнесреднеюрского комплекса.

В пределах мезозойского разреза преобладают подземные воды хлоридного натриевого типа. Меньше распространены воды хлоридно-гидрокарбонатного натриевого и гидрокарбонатно-хлоридного натриевого состава. Каждый тип имеет свои особенности распределения основных макрои микрокомпонентов. По мере роста величины общей минерализации происходит увеличение концентраций хлора, натрия, магния, кальция, калия, брома, йода, бора и аммония. Концентрации сульфат-иона в среднем не превышают 20-60 мг/дм, поскольку воды прошли десульфатизацию на иловой стадии в начале диагенеза.

На исследуемой территории выявлено доминирование инверсионного типа вертикальной гидрогеохимической зональности, охватывающего весь комплекс юрско-меловых отложений, - происходит снижение минерализации от 16-20 г/дм ${ }^{3}$ в аптальб-сеноманском комплексе до 5-10 г/дм ${ }^{3}$ и менее в водоносных горизонтах юрского возраста. Инверсия сопровождается сменой ионно-солевого состава подземных вод. С глубиной увеличиваются концентрации $\mathrm{HCO}_{3}$-иона, происходит переход от преимущественно хлоридного натриевого (на глубинах $\sim 2300$ м) к хлоридно-гидрокарбонатному натриевому и гидрокарбонатно-хлоридному натриевому типу вод.

Объяснение природы инверсионной гидрогеохимической зональности содержится в многочисленных гипотезах: современное и древнее разубоживание морских седиментационных вод инфильтрационными, преобразование органического вещества, конденсация паров воды при восходящей миграции углеводородных газов [Ginsburg, Ivanova, 1974; Shvartsev, Novikov, 2004]. Сегодня наиболее устоявшаяся у исследователей Западной Сибири 
точка зрения о причинах инверсии гидрогеохимического поля в арктических районах состоит в том, что пресные воды - результат разбавления морских седиментационных вод водой, отжимаемой из глин в процессе литификации (глины отдают свободную, а затем связанную воду). В экспериментальной работе П.А. Крюкова, А.А. Жучкова и Е.В. Ренгартена отмечается, что минерализация растворов, отжимаемых из глинистых пород, последовательно падает и при снижении величины общей минерализации изменение концентраций отдельных ионов неодинаково [Kryukov et al., 1962].

Таким образом, характер вертикальной гидрогеохимической зональности в пределах западной части ЕХРП определяется многими факторами: полнотой гидрогеологического разреза (наличием и выдержанностью водоупорных толщ), структурой гидродинамического поля, палеогидрогеологическими условиями (фации, состав и генезис захороняющихся сингенетичных вод), различными постседиментационными процессами в системе вода - горная порода - газ - органическое вещество, формированием и разрушением залежей УВ [Novikov, 2013, 2014, 2015, 2016; Kokh, Novikov, 2014; Sadykova, 2016; Sadykova, Dul'tseva, 2017].

Вопросами прогноза и оценки перспектив нефтегазоносности по гидрогеологическим критериям в пределах северных районов Западно-Сибирской НГП занимались Е.А. Барс, Г.Д. Гинсбург, Л.М. Зорькин, Г.А. Иванова, А.А. Карцев, А.Э. Конторович, В.А. Кротова, В.М. Матусевич, И.И.Нестеров, Р.Г. Прокопьева, Н.Н. Ростовцев, М.И. Суббота, Е.В. Стадник, В.Б. Торгованова и др. Первые попытки систематизировать гидрогеологические показатели были выполнены В.Т. Малышек в 30-х годах прошлого века. Позднее теоретические основы разрабатывались В.А. Сулиным, А.А. Карцевым, В.А. Кротовой, Ю.Г. Зиминым и многими другими исследователями.

Согласно существующим классификационным схемам, гидрогеологические критерии нефтегазоносности разделяют на региональные и локальные, прямые и косвенные, характеризующие условия формирования залежей, наличие скоплений УВ, сохранность и их фазовое состояние. Дальше критерии группируются в палеогидрогеологические, гидродинамические, геотермические и гидрогеохимические.

Как показали результаты наших исследований в региональном масштабе по общегидрогеологическим показателям, юрско-меловой разрез ЕХРП характеризуется благоприятными условиями для генерации и аккумуляции нефти и газа, подтверждает свою перспективную и высокую вероятность открытия здесь новых месторождений и обнаружения пропущенных залежей УВ. В регионе имеются коллекторы с высокими фильтрационно-емкостными свойствами, перекрытые надежными и регионально выдержанными водоупорами. Выделяются перспективные резервуары в зоне застойного водообмена в условиях хорошей закрытости недр на структурах, удаленных от прибортовых районов, где на протяжении всего времени существования осадочного бассейна имелись внешние области питания [Novikov, 2013].

Зональная стадия прогноза, выполненная на базе гидрогеологического районирования осадочного чехла (см. рис. 2), показывает, что наибольшие перспективы следует связывать с осевой частью прогиба, особенностями которой является глинизация проницаемой части верхнеюрского гидрогеологического комплекса (сиговский резервуар) ближе к восточному борту прогиба и далее в северо-западном направлении нижней части неокомских отложений (верхнесуходудинский, нижнесуходудинский, нижнехетско-суходудинский и нижнехетский резервуары).

Локальный прогноз нефтегазоносности дает ответ на вопрос, можно ли на разбуриваемой площади ожидать залежи УВ и где именно? Обширный гидрогеохимический материал, обобщенный в настоящей работе, диктует необходимость использования математических методов и компьютерных технологий для обработки данных, применение которых позволяет оперативно выявлять характеристики фонового состава подземных вод и гидрогеохимических аномалий. Фоновые воды характеризуются хлоридным натриевым составом с величиной общей минерализации от 3.0-4.0 г/дм ${ }^{3}$ до 13.0-15.0 г/дм ${ }^{3}$. Содержание $\mathrm{HCO}_{3}{ }^{-}$не превышает 950 мг/дм³; содержание $\mathrm{NH}_{4}{ }^{+}-$не более 8 мг/дм ${ }^{3}$, нафтеновых кислот - не выше 4 мг/дм³ ${ }^{3}$ Нефтегазопоисковая значимость гидрогеохимических показателей, связанных с зонами локализации УВ и участками разгрузки вод нижних горизонтов, на примере Западной Сибири показана в работах Н.М. Кругликова, В.М. Матусевича, В.М. Нелюбина, Р.Г. Прокопьевой и др.

В качестве гидрогеохимических критериев показателей нефтегазоносности используют разные компоненты ионно-солевого состава подземных вод, ВРГ, ОВ и их отношения. В состав критериев по исследуемой территории были выбраны: концентрации $\mathrm{SO}_{4}{ }^{2-}, \mathrm{HCO}_{3}{ }^{-}, \mathrm{Ca}^{2+}, \mathrm{NH}_{4}{ }^{+}, \mathrm{J}^{-}, \mathrm{Br}^{-}$, нафтеновых кислот, коэффициенты метаморфизации $\mathrm{rNa} / \mathrm{rCl}$, $\mathrm{Cl} / \mathrm{Br}, \mathrm{B} / \mathrm{Br}, \mathrm{rCa} / \mathrm{rMg}$, величина общей газонасыщенности подземных вод, концентрации метана, суммы тяжелых углеводородов (ТУ), азота и бензола.

Подземные воды Западной Сибири характеризуются низкой сульфатностью, пройдя стадию десульфатизации в начале диагенеза. Гидрокарбонат- 
ион является одним из важнейших поисковых показателей в пределах северной части ЗСМБ. Его повышенные концентрации, согласно А.М. Велькову, Ю.Г. Зимину, А.С. Зингеру, А.Э. Конторовичу, Е.В. Стаднику, М.И. Субботе и другим исследователям, могут рассматриваться как показатель наличия преимущественно газовых залежей. Источником $\mathrm{HCO}_{3}$-иона в подземных водах служат продукты преобразования ОВ, залежи УВ и связанные с ними конденсационные воды.

Работами многих исследователей показано, что ионы аммония и йода связаны с ОВ водовмещающих пород. Повышенные концентрации аммония свидетельствуют о первичном обогащении илов органикой и сохранении значительной части в седиментационных водах. Считается, что их накопление связано с переходом азотсодержащих компонентов нефтей в воду. Накоплению йода в морской воде препятствует жизнедеятельность организмов, активно извлекающих его из воды. Концентрирование йода в подземных водах происходит вследствие преобразования рассеянного органического вещества (РОВ) пород и высокой степени гидрогеологической закрытости недр [Beyko et al., 1988; Zor'kin, 1989; Polyushchuk, Yashchenko, 2004].

В подземных водах бром распространен повсеместно, в зонах затрудненного и застойного водообмена его концентрации достигают 500 мг/дм ${ }^{3}$ и более (при содержании в морской воде 65-70 мг/дм³ $)$. Повышенные концентрации брома указывают на степень метаморфизации подземных вод, а также отражают процессы преобразования ОВ, захороненного вместе с породами. Нафтеновые кислоты выступают в качестве важнейшего гидрогеохимического показателя, поскольку активно вовлечены в процесс диффузионного массопереноса между УВ залежью и пластовыми водами. Для ЕХРП установлена пороговая концентрация наличия залежи УВ - более 6 мг/дм³.

В качестве косвенных гидрогеологических показателей, указывающих на благоприятные условия, часто используют коэффициенты метаморфизации подземных вод $(\mathrm{rNa} / \mathrm{rCl}, \mathrm{Cl} / \mathrm{Br}, \mathrm{rCa} / \mathrm{rMg}, \mathrm{B} / \mathrm{Br}$ и других). B/Br коэффициент является наиболее информативным и характеризует наличие маломинерализованных (0.3-3.0 г/дм³) конденсационных вод преимущественно гидрокарбонатно-хлоридного натриевого состава. Помимо этого, они отличаются высокой газонасыщенностью (1.5 л/л и более) и локально развиты близ газоводяных контактов. Установлено, что этот генетический тип формируется при конденсации паров воды из водоуглеродной смеси при снижении пластового давления и температуры. В.Г. Козловым, Т.В. Левшенко и другими исследователями эмпирически установлено увеличение относительной концентрации органи- ческих кислот, аммония, ртути, бора, $\mathrm{HCO}_{3}$-иона и снижение содержаний хлора и брома. В работе А.Ю. Бычкова и Т.А. Киреевой [Kireyeva, Bychkov, 2011] показано, что соотношение $\mathrm{B} / \mathrm{Br}$ в морской воде не превышает 0.08-0.18 и практически не изменяется при изменении состава подземных вод в процессе катагенеза. При переходе подземных вод через паровую фазу в конденсате пара отношение $\mathrm{B} / \mathrm{Br}$ увеличивается, что связано с более высокой летучестью водорастворенных соединений бора (борной кислоты), чем соединений брома, что подтверждено результатами термодинамического моделирования.

Генетическое единство ВРГ подземных вод и УВ залежей нефти и газа является теоретической базой использования этих показателей для оценки перспектив нефтегазоносности. С одной стороны, растворенные газы играют определенную роль в формировании газовых скоплений, с другой - они являются наиболее активными компонентами системы «вода - газ» и создают водные ореолы рассеяния залежей в зонах ГВК и ВНК [Novikov, 2015]. В ЕХРП доказана высокая степень газонасыщенности подземных вод [Ginsburg, Afanasov, 1971]. ВРГ характеризуются метановым составом (углеводородных компонентов до 99 об. \%, содержание ТУ от сотых долей процента до 8.8 об. \%). С глубиной происходит «утяжеление» газового состава (рост содержаний гомологов метана). Анализ результатов гидрогеохимического опробования выявил зависимость изменения концентрации метана и ТУ в пластовых водах от фазового состава залежи. Количество ТУ закономерно увеличивается в объектах: «водонасыщенные» - смесь воды и газа - приконтурные воды газовых (газоконденсатных) залежей - воды нефтяных залежей (рис. 5, $a$ ).

Величина газонасыщенности подземных вод варьируется по площади и разрезу осадочного бассейна. Низкая газонасыщенность (менее 0.5 л/л) установлена на Долганской, Мессояхской и Суходудинской площадях. Аномалии по величине газонасыщенности выявлены по всему разрезу в неокомском гидрогеологическом комплексе (более 2.5 л/л) на Береговой и Дерябинской площадях, верхнеюрском комплексе (более 1.5 л/л) на Джангодской и Рассохинской площадях, нижнесреднеюрском комплексе (более 2.5 л/л) на структурах Аномальной, Пеляткинской и Средне-Яровской площадей.

Многочисленные фактические данные указывают на высокие содержания водорастворенного органического вещества (ВРОВ) в приконтурных водах залежей и низкие - в «пустых» структурах (без признаков нефтегазоносности). Среди всей водорастворенной органики особое место занимает бензол и его гомологи. Материалом по ВРОВ охарактеризован разрез от нижней юры до верх- 
a

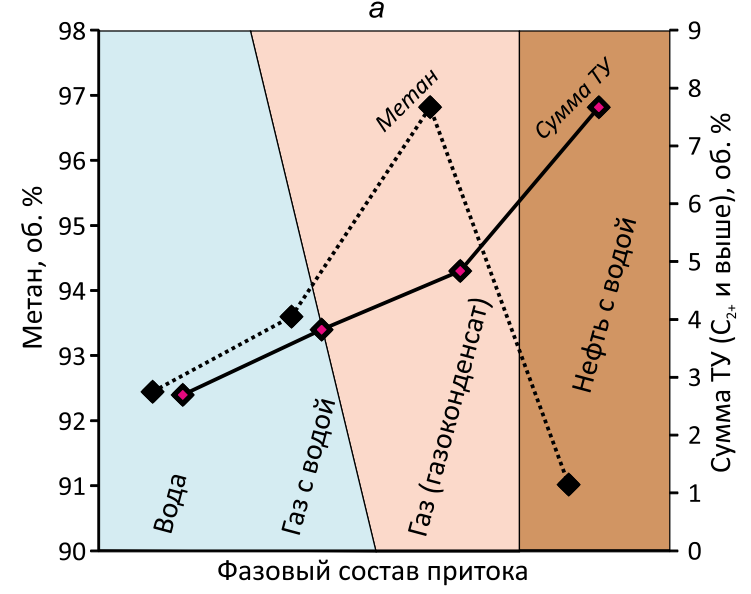

6

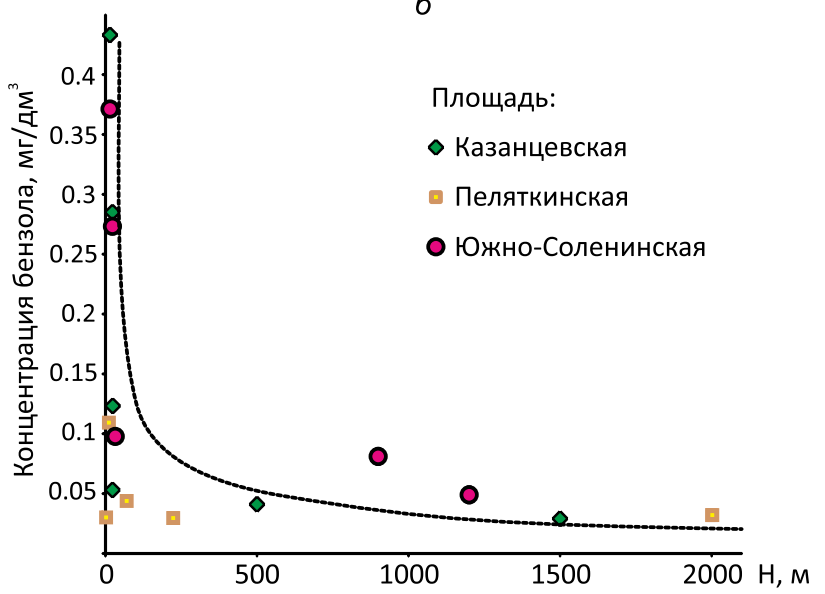

Рис. 5. Изменение концентрации метана и суммы ТУ в зависимости от фазового состава притока $(a)$ и бензола - от расстояния до контура нефтегазоносности (б).

Fig. 5. Variations in the concentrations of methane and the amount of heavy hydrocarbons, depending on the phase composition of the inflow (a), and benzene - from a distance to the contour of an oil-and-gas field (б).

него мела (Казанцевская, Пеляткинская, Южно-Соленинская площади). Изучены подземные воды газоносных и «пустых» горизонтов Джангодского, Малохетского, Нижнехетского, Озерного, Паютского, Тампейского и Тундрового поднятий. Воды со значительным содержанием бензола - 0.37 и 0.28 мг/дм ${ }^{3}$ - вскрыты в скважине № 7 Южно-Соленинской площади (пласт СД-IX) в интервале глубин 2860-2370 и 2377-2384 м соответственно [Ginsburg, Ivanova, 1977; Ivanova, 1973; Ivanova, Mel'kanovitskaya, 1973; Kartsev, 1982].

По характеру распределения бензола в водах установлено наличие вблизи залежей его повышенных концентраций (рис. 5, б). Ореольное рассеяние бензола указывает на малое расстояние от нефтяной залежи в большей степени, чем от газовой. По данным Г.А. Ивановой и С.Г. Мелькановицкой [Ivanova, Mel'kanovitskaya, 1973], гомологи бензола не обнаружены в водах горизонтов, не содержащих УВ, а также в водах газоносных горизонтов, залегающих на глубинах до 1000 м, что также отмечается в работе А.А. Карцева [Kartsev, 1982].

Применение методов математической статистики позволило выявить эталонные выборки и граничные значения по предложенному комплексу гидрогеологических критериев. Балльность критерия зависела от принадлежности к той или иной группе; например, группе наличия залежей УВ присвоен максимальный балл. Анализ комплекса критериев и их индивидуального вклада в общую оценку перспективности объектов выявил 16 высокоперспективных и 20 структур со средними перспективами для обоснования дальнейших нефтегазопоисковых работ на обнаружение пропущенных залежей и открытие новых месторожде- ний. Высокую результативность поисковых работ следует связывать с меловыми резервуарами (верхнесуходудинский и нижнехетский) на Нанадянской, Средне-Яровской, Токачинской, Турковской, Яровской и других площадях (рис. 6). В юрских отложениях следует ожидать открытия мелких и средних по запасам залежей, что подтверждается результатами геологоразведочных работ прошлых лет - открытием Зимнего (1966) и Хабейского (1982) месторождений. По предложенному комплексу гидрогеологических критериев в юрских резервуарах наиболее перспективным является малышевский резервуар на Дерябинской, Пеляткинской, Средне-Яровской, Тампейской, Турковской площадях, в меньшей степени - сиговский (Рассохинская и Суходудинская площади) и надояхский (Суходудинская площадь) резервуары. По результатам региональной оценки к наиболее перспективным, выделенным ранее М.А.Фоминым структурам [Fomin, 2011] отнесены: Среднетанамское куполовидное поднятие, Верхнеянгодинский и Южно-Хучетовский наклонные валы, Луцимпяяхинский, Муссуйяхинский и Харвутаяхинский структурные мысы. К перспективным структурам, характеризующим благоприятные условия формирования и сохранности залежей УВ, отнесены Восточно-Ямбутовский структурный мыс, Нижнепаелаваяхинское и Южно-Суходудинское куполовидные поднятия, а также Лайдинский наклонный вал.

\section{3. ЗАКЛЮЧЕНИЕ}

Как показали проведенные исследования, водонапорная толща западной части ЕХРП формирова- 


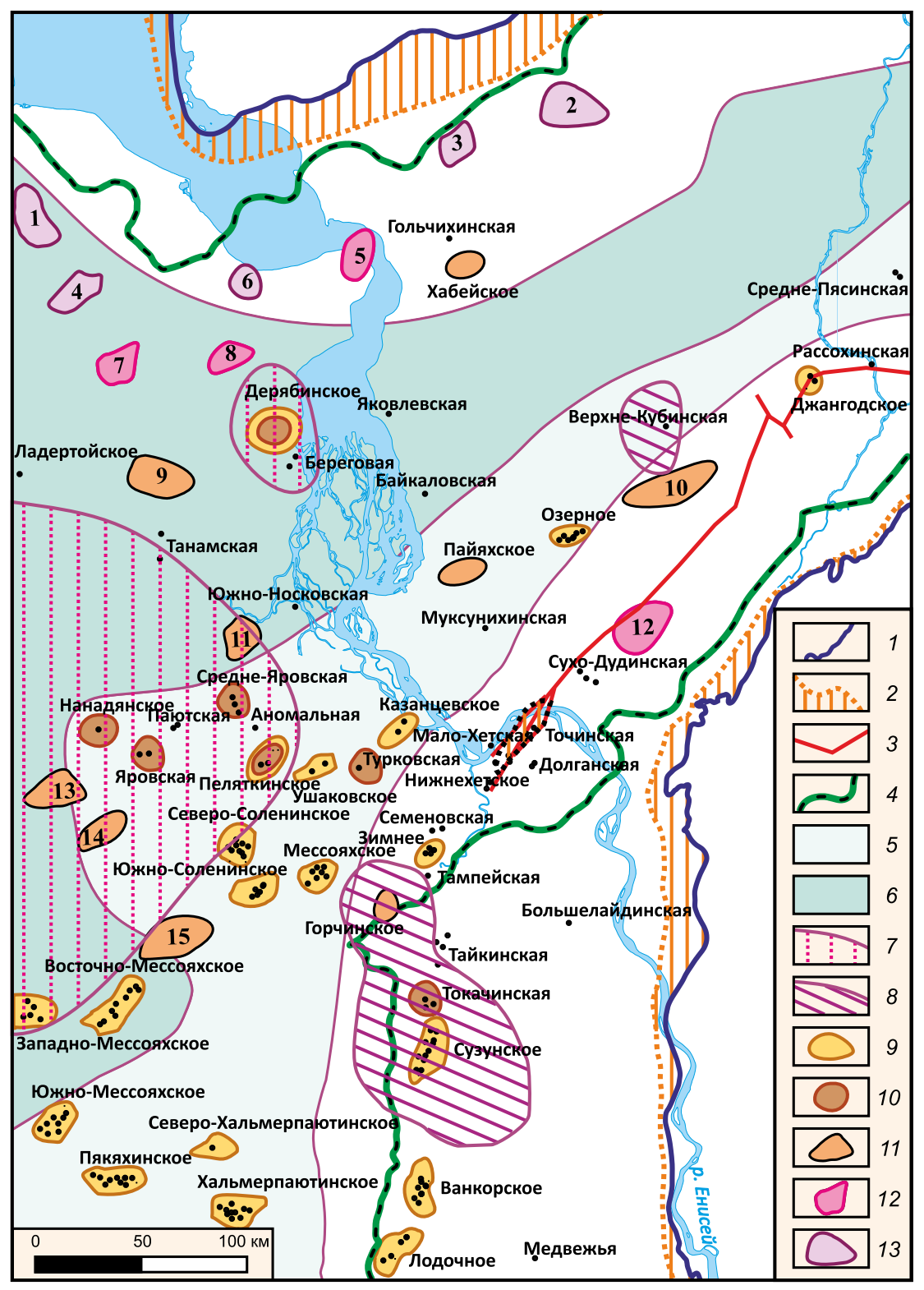

Рис. 6. Карта-схема перспектив нефтегазоносности неокомских отложений западной части Енисей-Хатангского регионального прогиба по гидрогеологическим данным.

1-4 - границы: 1 - распространения мезозойско-кайнозойского осадочного чехла, 2 - отсутствия отложений комплекса, 3 дизъюнктивных нарушений, 4- внешней тектонической области; 5-6 - особенности строения (глинизация): 5 - сиговский резервуар верхней юры, 6 - сиговский резервуар верхней юры и меловые резервуары (нижнехетский, нижнехетско-суходудинский и нижнесуходудинский); 7-8 - гидрогеохимические аномалии: 7 - по газонасыщенности подземных вод (>2.5 л/л), 8 - по содержанию иона аммония (>25 мг/дм³); 9 - площади с доказанной нефтегазоносностью; 10-13 - категории перспективных структур: 10 - высокоперспективные, 11 - среднеперспективные, 12 - перспективные, 13 - низкоперспективные. Новые структуры 3-го порядка: 1 - Сурыяхинское куполовидное поднятие (кп), 2 - Усть-Буотанкагский структурный мыс (см), 3 - Быстровский см, 4 - Есяяхинское кп, 5 - Лайдинский наклонный вал (нв), 6 - Периптаветское кп, 7 - Восточно-Ямбутовский см, 8 - Нижнепаелаваяхинское кп, 9 - Южно-Хучетовский нв, 10 - Верхнеянгодинский нв, 11 - Среднетанамское кп, 12 - Южно-Суходудинское кп, 13 - Муссуйяхинский см, 14 - Луцимпяяхинский см, 15 - Харвутаяхинский см.

Fig. 6. Schematic map showing the petroleum potential of the Neocomian deposists in the western segment of the YeniseiKhatanga regional trough, as assessed from the hydrogeological data.

1-4 - boundaries: 1 - Meso-Cenozoic sedimentary cover, 2 - no deposits, 3 - faults, 4 - external tectonic area; 5-6 - structural features (argillization): 5 - Sigov reservoir of Upper Jurassic, 6 - Sigov reservoir of Upper Jurassic and Cretaceous reservoirs (Lower Tekhet, Lower Tekhet-Sukhodudinka and Lower Sukhodudinka); 7-8 - hydrogeochemical anomalies: 7 - gas saturation of groundwater (>2.5 l/l), 8 concentration of ammonium ion ( $>25 \mathrm{mg} / \mathrm{dm}^{3}$ ); 9 - proved oil-and-gas fields; $10-13$ - promising structures by categories: 10 - high potential, 11 - medium potential, 12 - potential, 13 - low potential. New structures of the $3^{\text {rd }}$ order: 1 - Suryyakh dome-shaped uplift, 2 - Ust Buotankag structure, 3 - Bystrov structure, 4 - Esyayakh dome-shaped uplift, 5 - Laidin sloping rampart, 6 - Periptavet dome-shaped uplift, 7 - East Yambutov structure, 8 - Lower Paelavayakh dome-shaped uplift, 9 - South Khuchetov sloping rampart, 10 - Upper Yangoda sloping rampart, 11 - Srednetanam dome-shaped uplift, 12 - South Sukhodudinka dome-shaped uplift, 13 - Mussuiyakh structure, 14 Lutsimpyayakh structure, 15 - Kharvutayakh structure. 
лась на протяжении длительной геологической истории. Установлены восемь типов гидрогеологического разреза и границы между ними. Особое значение на настоящем этапе ее развития приобрела мощная криогенная толща, дополнительно экранирующая, наравне с региональным турон-олигоценовым водоупором, меловые и юрские нефтегазоносные комплексы от промыва инфильтрационными водами. Вследствие высокой степени гидрогеологической закрытости недр, процессов элизионного водообмена при уплотнении глинистых толщ сформировались гидрогеохимические и гидродинамические условия, типичные для элизионной литостатической водонапорной системы, - инверсионный тип вертикальной гидрогеохимической зональности, повышенные и аномально высокие пластовые давления в низах неокомского и в пределах малышевского резервуара нижнесреднеюрского комплекса.

В пределах мезозойского разреза преобладают подземные воды хлоридного натриевого типа. Меньше распространены воды хлоридно-гидрокарбонатного натриевого и гидрокарбонатно-хлоридного натриевого состава. По мере роста величины общей минерализации происходит увеличение концентраций хлора, натрия, магния, кальция, калия, брома, йода, бора и аммония. Концентрации сульфат-иона в среднем не превышают 2060 мг/дм³ , поскольку воды прошли десульфатизацию на иловой стадии в начале диагенеза. На исследуемой территории выявлено доминирование инверсионного типа вертикальной гидрогеохимической зональности, охватывающего весь комплекс отложений - происходит уменьшение минерализации от 16-20 г/дм ${ }^{3}$ в апт-альб-сеноманском комплексе до 5-10 г/дм ${ }^{3}$ и менее в водоносных горизонтах юрского возраста. Инверсия сопровождается сменой ионно-солевого состава подземных вод. С глубиной увеличиваются концентрации $\mathrm{HCO}_{3}$-иона, происходит переход от преимущественно хлоридного натриевого (на глубинах 2300 м) к хлоридно-гидрокарбонатному натриевому и гидрокарбонатно-хлоридному натриевому типу вод.

Региональный прогноз, оценивающий юрскомеловой разрез ЕХРП по общегидрогеологическим показателям, свидетельствует о благоприятных условиях для генерации и аккумуляции нефти и га- за, подтверждает высокую вероятность открытия здесь новых месторождений и обнаружения пропущенных залежей УВ. В регионе имеются коллекторы с высокими фильтрационно-емкостными свойствами, перекрытые надежными и регионально выдержанными водоупорами. Выделяются перспективные резервуары в зоне застойного водообмена в условиях хорошей закрытости недр на структурах, удаленных от прибортовых районов, где на протяжении всего времени существования осадочного бассейна были внешние области питания. Зональная стадия прогноза, выполненная на базе гидрогеологического районирования осадочного чехла, показывает, что наибольшие перспективы следует связывать с осевой частью прогиба, особенностями которой является глинизация проницаемой части верхнеюрского гидрогеологического комплекса (сиговский резервуар) ближе к восточному борту прогиба и далее в северо-западном направлении нижней части неокомских отложений (верхнесуходудинский, нижнесуходудинский, нижнехетско-суходудинский и нижнехетский резервуары). Локальный прогноз нефтегазоносности, основанный на детальном анализе ионно-солевого состава подземных вод, ВРГ, ОВ, позволил выявить 16 высокоперспективных и 20 структур со средними перспективами для обоснования дальнейших нефтегазопоисковых работ на обнаружение пропущенных залежей и открытие новых месторождений. Высокую результативность поисковых работ следует связывать с меловыми резервуарами (верхнесуходудинский и нижнехетский). В юрских отложениях наиболее перспективным для открытия новых залежей является малышевский резервуар, в меньшей степени сиговский и надояхский.

\section{4. БЛАГОДАРНОСТИ}

Исследования проводились при финансовой поддержке СО РАH (проект VIII.73.3.3. «Гидрогеохимия и механизмы формирования состава подземных вод арктических районов Западно-Сибирского осадочного бассейна» Программы фундаментальных исследований VIII.73.3. «Эволюция гидрогеологических систем осадочных бассейнов Сибири») и РФФИ (проекты № 14-05-00868-a, 16-0500945-a).

\section{5. ЛИTEPATУРA / REFERENCES}

Baskov E.A., Klimov G.I., Kiryukhin V.A., Surikov S.N., Petrova N.A., Tolstikhin O.N., 1974. Hydrogeological structures of East Siberia, the Far East and the Northeast of the USSR. In: I.K. Zaitsev (Ed.), Main types of hydrogeological structures in the USSR. VSEGEI, Leningrad, p. 70-83 (in Russian) [Басков Е.А., Климов Г.И., Кирюхин В.А., Суриков С.Н., Петрова Н.А., Толстихин О.Н. Гидрогеологические структуры Восточной Сибири, Дальнего Востока и северо-востока СССР // Основные типы гидрогеологических структур СССР / Ред. И.К. Зайцев. Л.: ВСЕГЕИ, 1974. C. 70-83]. 
Baulin V.V., Belopukhova E.B., Dubikov G.I., Shmelev L.M., 1967. Geocryological Conditions of the West Siberian Lowland. Nauka, Moscow, 214 p. (in Russian) [Баулин В.В., Белопухова Е.Б., Дубиков Г.И., Шмелев Л.М. Геокриологические условия Западно-Сибирской низменности. М.: Наука, 1967. 214 с.].

Beyko O.A., Golovko A.K., Gorbunova L.V., Kam'yanov V.F., Lebedev A.K., Plyusnin A.N., Savinykh Yu.V., Sivirilov P.P., Filimonova T.A., 1988. Chemical Composition of Oils in West Siberia. Siberian Branch, Nauka, Novosibirsk, 288 p. (in Russian] [Бейко О.А., Головко А.К., Горбунова Л.В., Камьянов В.Ф., Лебедев А.К., Плюснин А.Н., Савиных Ю.В., Сивирилов П.П., Филимонова Т.А. Химический состав нефтей Западной Сибири. Новосибирск: Наука. Сибирское отделение, 1988. 288 с.].

Borodkin V.N., Kurchikov A.R., 2015. To the problem of refining the western and eastern boundaries of the Achimov clinoform complex (West Siberia). Russian Geology and Geophysics 56 (9), 1281-1291. https://doi.org/10.1016/ j.rgg.2015.08.005.

Bro E.G., 1977. Experience of studying the variability of groundwater mineralization in the Jurassic-Cretaceous section of North Siberia based on field and geophysical data. In: D.S. Sorokov (Ed.), Geology and petroleum potential of Mesozoic troughs in the northern areas of the Siberian platform. NIIGA, Leningrad, p. 58-69 (in Russian) [Бро Е.Г. Опыт изучения изменчивости минерализации подземных вод в юрско-меловом разрезе севера Сибири с привлечением промыслово-геофизических данных // Геология и нефтегазоносность мезозойских прогибов севера Сибирской платформы / Ред. Д.С. Сороков. Л.: НИИГА, 1977. С. 58-69].

Bro E.G., Ivanova G.A., Ginsburg G.D., 1973. On inversion hydrogeochemical zoning of gas condensate fields in the western segment of the Yenisei-Khatanga trough. In: Abstracts of the $7^{\text {th }}$ Conference on Groundwater in Siberia and the Far East. Irkutsk-Novosibirsk, p. 36-45 (in Russian) [Бро Е.Г., Иванова Г.А., Гинсбург Г.Д. Об инверсионной гидрогеохимической зональности на газоконденсатных месторождениях западной части ЕнисейХатангского прогиба // Тезисы докладов VII совещания по подземным водам Сибири и Дальнего Востока. Иркутск-Новосибирск, 1973. С. 36-45].

Dobretsov N.L., Polyansky O.P., Reverdatto V.V., Babichev A.V., 2013. Dynamics of the Arctic and adjacent petroleum basins: a record of plume and rifting activity. Russian Geology and Geophysics 54 (8), 888-902. https://doi.org/ 10.1016/j.rgg.2013.07.009.

Dolmatova I.V., Peshkova I.N., 2001. Model of rifting in the northern paleo-margin of the Siberian continent (YeniseiKhatanga trough). Geologiya, Geofizika i Razrabotka Neftyanykh Mestorozhdeniy (Geology, Geophysics and Development of Oil Fields) (7), 30-33 (in Russian) [Долматова И.В., Пешкова И.Н. Модель рифтовой деструкции северной палеоокраины Сибирского континента (Енисей-Хатангский прогиб) // Геология, геофизика и разработка нефтяных месторождений. 2001. № 7. С. 30-33].

Fomin M.A., 2011. Analysis of the tectonic structure of the Meso-Cenozoic sedimentary cover of the Yenisei-Khatanga regional trough by reference horizons, and tectonic conditions for its oil-and-gas-bearing capacities. Geologiya, Geofizika i Razrabotka Neftyanykh Mestorozhdeniy (Geology, Geophysics and Development of Oil Fields) (9), 4-20 (in Russian) [Фомин M.A. Анализ тектонического строения мезозойско-кайнозойского осадочного чехла Енисей-Хатангского регионального прогиба по опорным горизонтам, тектонические предпосылки его нефтегазоносности // Геология, геофизика и разработка нефтяных и газовых месторождений. 2011. № 9. C. 4-20].

Ginsburg G.D., Afanasov Yu.A., 1971. Manifestation of free gases and water-soluble gases. Gas composition. In: D.S. Sorokov (Ed.), Geology and petroleum potential of the Yenisei-Khatanga trough. Nedra, Leningrad, p. 110-116 (in Russian) [Гинсбург Г.Д., Афанасов Ю.А. Проявление свободных газов и водорастворенные газы. Состав газов // Геология и нефтегазоносность Енисей-Хатангского прогиба / Ред. Д.С. Сороков. Л.: Недра, 1971. C. 110-116].

Ginsburg G.D., Ivanova G.A., 1971. Groundwaters. In: D.S. Sorokov (Ed.), Geology and petroleum potential of the Yenisei-Khatanga trough. Nedra, Leningrad, p. 66-72 (in Russian) [Гинсбург Г.Д., Иванова Г.А. Подземные воды // Геология и нефтегазоносность Енисей-Хатангского прогиба / Ред. Д.С. Сороков. Л.: Недра, 1971. С. 66-72].

Ginsburg G.D., Ivanova G.A., 1974. Main geochemical features of groundwater in the Jurassic-Cretaceous bed of the southwestern segment of the Yenisei-Khatanga oil-gas province. In: D.S. Sorokov, G.D. Ginsburg (Eds.), YeniseiKhatanga oil-gas province. NIIGA, Leningrad, p. 71-85 (in Russian) [Гинсбург Г.Д., Иванова Г.А. Основные черты геохимии подземных вод в юрско-меловой толще юго-западной части Енисей-Хатангской нефтегазоносной области // Енисей-Хатангская нефтегазоносная область / Ред. Д.С. Сороков, Г.Д. Гинсбург. Л.: НИИГА, 1974. C. 71-85].

Ginsburg G.D., Ivanova G.A., 1977. Some characteristic features of geochemical zoning of groundwaters in the southwestern segment of the Yenisei-Khatanga trough. In: D.S. Sorokov (Ed.), Geology and petroleum potential of the Mesozoic troughs in the north areas of the Siberian platform. NIIGA, Leningrad, p. 70-82 (in Russian) [Гинсбург Г.Д., Иванова Г.А. Некоторые характерные черты геохимической зональности подземных вод в юго-западной части Енисей-Хатангского прогиба // Геология и нефтегазоносность мезозойских прогибов севера Сибирской платформы / Ред. Д.С. Сороков. Л.: НИИГА, 1977. С. 70-82].

Ginsburg G.D., Ivanova G.A., Sapir M.Kh., 1969. About groundwaters of the Ust-Yenisei basin. In: N.I. Tolstikhin, G.D. Ginsburg (Eds.), Hydrogeology of the Yenisei North. Vol. 1. NIIGA, Leningrad, p. 6-23 (in Russian) [Гинсбург Г.Д., Иванова Г.А., Сапир М.X. О подземных водах Усть-Енисейской впадины // Гидрогеология Енисейского севера / Ред. Н.И. Толстихин, Г.Д. Гинсбург. Вып. 1. Л.: НИИГА, 1969. С. 6-23].

Golovin S.V., 2009. Classification of Mesozoic oil-gas complexes of the Yenisei-Khatanga trough. Neftegazovaya Geologiya. Teoriya i Praktika (Oil and Gas Geology. Theory and Practice) 4 (1), Article No. 12_2009 (in Russian) [Голо- 
вин С.В. Классификация нефтегазоносных комплексов мезозоя Енисей-Хатангского прогиба // Нефтегазовая геология. Теория и практика. 2009. Т. 4. № 1. Статья № 12_2009]. Available from: http://www.ngtp.ru/ rub/4/12_2009.pdf.

Grechishchev S.E., Mel'nikov E.S., Moskalenko N.G., 1983. Geocryological Forecast for the West Siberian Gas Province. Nauka, Novosibirsk, 180 p. (in Russian) [Гречищев C.E., Мельников Е.С., Москаленко Н.Г. Геокриологический прогноз для Западно-Сибирской газоносной провинции. Новосибирск: Наука, 1983. 180 с.].

Isayev A.V., Devyatov V.P., Karpukhin S.M., Krinin V.A., 2010. Oil and gas prospects of Enisei-Khatangsky regional trough. Geologiya Nefti i Gaza (Oil and Gas Geology) (4), 13-23 (in Russian) [Исаев А.В., Девятов В.П., Карпухин С.М., Кринин B.A. Перспективы нефтегазоносности Енисей-Хатангского регионального прогиба // Геология нефти и газа. 2010. № 4. С. 13-23].

Ivanova G.A., 1973. Features of Geochemistry of Groundwater in the Southwestern Yenisei-Khatanga Oil-Gas Province. PhD Thesis (Candidate of Geology and Mineralogy). Sevmorgeo, Norilsk, 226 p. (in Russian) [Иванова Г.А. Особенности геохимии подземных вод юго-западной части Енисей-Хатангской нефтегазоносной области: Дис. ... канд. геол.-мин. наук. Норильск: Севморгео, 1973. 226 с.].

Ivanova G.A., Mel'kanovitskaya S.G., 1973. Benzene and its homologues in the formation waters of the Yenisei-Khatanga trough. Geologiya Nefti i Gaza (Oil and Gas Geology) (2), 27-34 (in Russian) [Иванова Г.А., Мелькановицкая С.Г. Бензол и его гомологи в пластовых водах Енисей-Хатангского прогиба // Геология нефти и газа. 1973. № 2. C. 27-34].

Kartsev A.A., 1982. Hydrogeological indicators for oil and gas exploration. In: V.V. Kolody (Ed.), Hydrogeology of petroleum provinces. Naukova dumka, Kiev, p. 61-66 (in Russian) [Карцев А.А. Нефтегазопоисковые гидрогеологические показатели // Гидрогеология нефтегазоносных провинций / Ред. В.В. Колодий. Киев: Наукова думка, 1982. С. 61-66].

Kartsev A.A., Vagin S.B., Matusevich V.M., 1986. Hydrogeology of Oil- and Gas-Bearing Basins. Nedra, Moscow, 224 p. (in Russian) [Карцев А.А., Вагин С.Б., Матусевич В.М. Гидрогеология нефтегазоносных бассейнов. М.: Недра, 1986. 224 c.].

Kireyeva T.A., Bychkov A.Yu., 2011. New method of condensation water diagnostics of fields in West Siberia. Geologiya Nefti i Gaza (Oil and Gas Geology) (2), 103-108 (in Russian) [Киреева T.A., Бычков А.Ю. Новый метод диагностики конденсационных вод нефтегазоносных месторождений Западной Сибири // Геология нефти и газа. 2011. № 2. C. 103-108].

Kokh A.A., Novikov D.A., 2014. Hydrodynamic conditions and vertical hydrogeochemical zonality of groundwater in the Western Khatanga artesian basin. Water resources 41 (4), 396-405. https://doi.org/10.1134/S00978078140 40083.

Kontorovich A.E., Ershov S.V., 2010. Oil and gas reserves of West Siberia. Nauka iz pervykh ruk (Science First Hand) 33 (3), 26-29 (in Russian) [Конторович А.Э., Ершов С.В. Нефтегазовый резерв Западной Сибири // Наука из первых рук. 2010. Т. 33. № 3. С. 26-29].

Kontorovich A.E., Grebenuk V.V., Kuznetsov L.L., Kulikov D.P., Khmelevski V.B., Azarnov A.N., Nakaryakov V.D., Polyakova I.D., Sibgatullin V.G., Soboleva E.I., Starosel'tsev V.S., Stepanenko G.F., Fradkin G.S., 1994. Oil- and Gas-Bearing Basins and Regions of Siberia. Vol. 3. Yenisei-Khatanga Basin. OIGGM SB RAS, Novosibirsk, 71 p. (in Russian) [Конторович А.Э., Гребенюк В.В., Кузнецов Л.Л., Куликов Д.П., Хмелевский В.Б., Азарнов А.Н., Накаряков В.Д., Полякова И.Д., Сибгатуллин В.Г., Соболева Е.И., Старосельцев В.С., Степаненко Г.Ф., Фрадкин Г.С. Нефтегазоносные бассейны и регионы Сибири. Вып. 3. Енисей-Хатангский бассейн. Новосибирск: ОИГгМ СО РАН, 1994. 71 с.].

Kontorovich V.A., 2011. The tectonic framework and hydrocarbon prospectivity of the western Yenisei-Khatanga regional trough. Russian Geology and Geophysics 52 (8), 804-824. https://doi.org/10.1016/j.rgg.2011.07.006.

Kruglikov N.M., Nelyubin V.V., Yakovleva O.N., 1985. Hydrogeology of the West Siberian Oil- and Gas-Bearing Megabasin and Formation Features of Hydrocarbon Deposits. Nedra, Leningrad, 279 p. (in Russian) [Кругликов Н.М., Нелюбин В.В., Яковлева О.Н. Гидрогеология Западно-Сибирского нефтегазоносного мегабассейна и особенности формирования залежей углеводородов. Л.: Недра, 1985. 279 с.].

Kryukov P.A., Zhuchkova A.A., Rengarten E.V., 1962. Changes in the composition of solutions from clay and ion-exchange resins. Doklady AN SSSR 144 (6), 1363-1402 (in Russian) [Крюков П.А., Жучкова А.А., Ренгартен Е.В. Изменение состава растворов, отжимаемых из глин и ионообменных смол // Доклады АН СССР. 1962. T. 144. № 6. C. 1363-1402.

Kurchikov A.R., Borodkin V.N., 2015. Characteristics of Geological Structure and Petroleum Potential of Jurassic Oil- and Gas-Bearing Complex in West Siberia. Publishing House of RAS, Novosibirsk, 140 p. (in Russian] [Курчиков А.P., Бородкин В.Н. Характеристика геологического строения и нефтегазоносности юрского нефтегазоносного комплекса Западной Сибири. Новосибирск: Изд-во СО РАН, 2015. 140 с.].

Matusevich V.M., Ryl'kov A.V., Ushatinsky I.N., 2005. Geofluidal Systems and Problems of Petrpleum Potential in West Siberian Megabasin. Tyumen State Technical University, Tyumen, 225 p. (in Russian) [Матусевич В.М., Рыльков А.В., Ушатинский И.Н. Геофлюидальные системы и проблемы нефтегазоносности Западно-Сибирского мегабассейна. Тюмень: ТюмГНГУ, 2005. 225 с.].

Novikov D.A., 2013. Hydrogeology of the western part of the Yenisei-Khatanga regional trough. Neftegazovaya Geologiya. Teoriya i Praktika (Oil and Gas Geology. Theory and Practice) 8 (1), Article No. 2_2013 (in Russian) [Hовuков Д.А. Гидрогеология западной части Енисей-Хатангского регионального прогиба // Нефтегазовая геология. Теория и практика. 2013. Т. 8. № 1. Статья № 2_2013]. https://doi.org/10.17353/2070-5379/2_2013. 
Novikov D.A., 2014. Hydrodynamics of the Neocomian oil and gas fields in the transition region from the West Siberian artesian basin to the Khatanga basin. Geologiya, Geofizika i Razrabotka Neftyanykh i Gazovykh Mestorozhdeniy (Geology, Geophysics and Development of Oil and Gas Fields) (2), 24-33 (in Russian) [Новиков Д.А. Гидродинамика нефтегазоносных отложений неокома переходной области от Западно-Сибирского артезианского бассейна к Хатангскому // Геология, геофизика и разработка нефтяных и газовых месторождений. 2014. № 2. C. 24-33].

Novikov D.A., 2015. Oil and gas prospecting: Water-gas equilibrium studies, application aspects. Gazovaya Promyshlennost' (Gas Industry) (3), 12-17 (in Russian) [Новиков Д.А. Применение методики поисков залежей углеводородов на основе изучения водно-газовых равновесий // Газовая промышленность. 2015. № 3. С. 12-17].

Novikov D.A., 2016. Hydrogeochemistry of catagenetic transformation processes in sedimental rocks of petroleum deposits in the Arctic districts of the West Siberian megabasin. Izvestia vuzov. Neft i gaz (Higher Educational Institutions News. Oil and Gas) (6), 19-25 (in Russian) [Новиков Д.А. Гидрогеохимия процессов катагенетического преобразования осадочных пород нефтегазоносных отложений арктических районов Западно-Сибирского мегабассейна // Известия вузов. Нефть и газ. 2016. № 6. С. 19-25].

Nudner V.A., 1970. Hydrogeology of the USSR. Vol. XVI. Nedra, Moscow, 368 p. (in Russian) [Нуднер В.А. Гидрогеология СССР. T. XVI. М.: Недра, 1970. 368 с.].

Polyakov A.A., Fomina E.V., Isaev A.V., Karpukhin S.M., 2012. New directions of geological exploration in the western Yenisei-Khatanga trough (right bank of the Yenisei river). In: Scientific and technical bulletin of OJSC NK ROSNEFT, vol. 26, p. 2-7 (in Russian) [Поляков А.А., Фомина Е.В., Исаев А.В., Карпухин С.М. Новые направления геологоразведочных работ на западе Енисей-Хатангского прогиба (правобережье Енисея) // Научно-технический вестник ОАО «НК РОСНЕФТЬ». 2012. Вып. 26. С. 2-7].

Polyushchuk Yu.M., Yashchenko I.G., 2004. Physico-Chemical Properties of Oils: Statistical Analysis of Spatial and Temporal Variations. Geo Branch, Publishing House of RAS, Novosibirsk, 109 p. (in Russian) [Полюшук Ю.М., Ященко И.Г. Физико-химические свойства нефтей: ститистический анализ пространственных и временных изменений. Новосибирск: Изд-во СО РАН, филиал «Гео», 2004. 109 с.].

Pronkin A.P., Savchenko V.I., Khlebnikov P.A., Ernst V.A., Filiptsov Yu.A., Afanasenkov A.P., Efimov A.S., Stupakova A.V., Bordunov S.I., Suslova A.A., Sautkin R.S., Glukhova T.A., Peretolchin K.A., 2012. New data about geological structure and possible oil and gas potential of the West-Siberian and Siberian platform jointing zone with folded Taimyr. Geologiya Nefti i Gaza (Oil and Gas Geology) (1), 28-42 (in Russian) [Пронкин А.П., Савченко В.И., Хлебников П.А., Эрнст В.А., Филипцов Ю.А., АФанасенков А.П., Ефимов А.С., Ступакова А.В., Бордунов С.И., Суслова А.А., Сауткин Р.С., Глухова Т.А., Перетолчин К.А. Новые данные о геологическом строении и возможной нефтегазоносности зон сочленения Западно-Сибирской и Сибирской платформ со складчатым Таймыром // Геология нефти и газа. 2012. № 1. С. 28-42].

Ravdonikas O.V., 1962. Main Results of Hydrogeological Studies of Oil Regions in the Northern West Siberia. Proceedings of NIIGA, vol. 129. Gosgeoltekhizdat, Moscow, 194 p. (in Russian) [Равдоникас О.В. Основные итоги гидрогеологических исследований нефтеносных районов севера Западной Сибири. Труды НИИГА. Вып. 129. М.: Госгеолтехиздат, 1962. 194 с.].

Rosenbaum G.E., Shpolyanskaya N.A., 2000. Late Cenozoic History of the Arctic Permafrost Zone and Trends of Its Future Development. Nauchny Mir, Moscow, 103 p. (in Russian) [Розенбаум Г.Э., Шполянская Н.А. Позднекайнозойская история криолитозоны Арктики и тенденции ее будущего развития. М.: Научный мир, 2000. 103 c.].

Rostovtsev N.N., Ravdonikas O.V., 1958. Geological Structure and Prospects of Petroleum Potential of the West Siberian Lowland. Gostoptekhizdat, Moscow, 391 p. (in Russian] [Ростовцев Н.Н., Равдоникас О.В. Геологическое строение и перспективы нефтегазоносности Западно-Сибирской низменности. М.: Гостоптехиздат, 1958. 391 с.].

Rozin A.A., 1977. Groundwaters of West Siberian Artesian Basin and Their Formation. Nauka, Novosibirsk, 102 p. (in Russian) [Розин A.A. Подземные воды Западно-Сибирского артезианского бассейна и их формирование. Новосибирск: Наука, 1977. 102 с.].

Sadykova Ya.V., 2016. Paleohydrogeochemical reconstruction of oil and gas bearing deposits of the Gydan peninsula. Otechestvennaya geologiya (Russian Geology) (1), 16-24 (in Russian) [Садыкова Я.В. Палеогидрогеохимические реконструкции нефтегазоносных отложений полуострова Гыдан // Отечественная геология. 2016. № 1. C. 16-24].

Sadykova Ya.V., Dul'tseva M.G., 2017. The role of paleohydrochemical factors in groundwater chemistry formation in oil-and-gas-bearing deposits of the northeastern Bol'shekhetskaya Megasyneclise. Water Resources 44 (2), 246-258. https://doi.org/10.1134/S0097807817020130.

Shvartsev S.L., Novikov D.A., 2004. The nature of vertical hydrogeochemical zoning of petroleum deposits (exemplified by the Nadym-Taz interfluve, West Siberia). Geologiya i Geofizika (Russian Geology and Geophysics) 45 (8), 1008-1020.

Stoupakova A.V., Bordunov S.I., Sautkin R.S., Suslova A.A., Peretolchin K.A., Sidorenko S.A., 2013. Russian Arctic oil and gas basins. Geologiya Nefti i Gaza (Oil and Gas Geology) (3), 30-47 (in Russian) [Ступакова А.В., Бордунов С.И., Сауткин Р.С., Суслова А.А., Перетолчин К.А., Сидоренко С.А. Нефтегазоносные бассейны Российской Арктики // Геология нефти и газа. 2013. № 3. С. 30-47].

Torgovanova V.B., Dubrova N.V., Kruglikov N.M., 1960. Waters and Gases in Paleozoic and Mesozoic Deposits of West Siberia. Proceedings of VNIGRI, vol. 159. Gostoptekhizdat, Leningrad, 460 p. (in Russian) [Торгованова В.Б., Дуб- 
рова Н.В., Кругликов Н.М. Воды и газы палеозойских и мезозойских отложений Западной Сибири. Труды ВНИГРИ. Вып. 159. Л.: Гостоптехиздат, 1960. 460 с.].

Trofimov V.T., Vasil'chuk Yu.K., 1987. Geocryological Zoning of the West Siberian Plate. Nauka, Moscow, 222 p. (in Russian] [Трофимов B.T., Васильчук Ю.К. Геокриологическое районирование Западно-Сибирской плиты. М.: Наука, 1987. 222 с.].

Zaitsev I.K., 1972. Hydrogeology of the USSR. Vol. XVIII. Nedra, Moscow, 479 p. (in Russian) [Зайцев И.К. Гидрогеология ССCР. T. XVIII. М.: Недра, 1972. 479 с.].

Zor'kin L.M., 1989. Waters in Oil and Gas Fields of the USSR. Nedra, Moscow, 382 p. (in Russian) [Зорькин Л.М. Воды нефтяных и газовых месторождений СССР. М.: Недра, 1989. 382 с.].

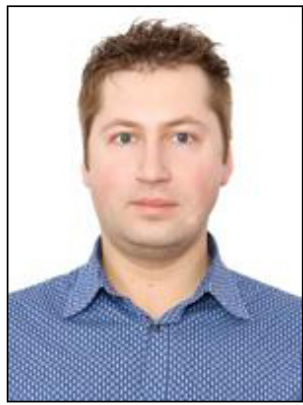

Новиков Дмитрий Анатольевич, канд. геол.-мин. наук, зав. лабораторией Институт нефтегазовой геологии и геофизики им. А.А. Трофимука СО РАН 630090, Новосибирск, пр. Академика Коптюга, 3, Россия

Новосибирский национальный исследовательский государственный университет 630090, Новосибирск, ул. Пирогова, 2, Россия

Тел.: +7(383)3638036; e-mail: NovikovDA@ipgg.sbras.ru

Novikov, Dmitry A., Candidate of Geology and Mineralogy, Head of Laboratory

A.A. Trofimuk Institute of Petroleum Geology and Geophysics, Siberian Branch of RAS

3 Academician Koptug ave., Novosibirsk 630090, Russia

Novosibirsk National Research State University

2 Pirogov street, Novosibirsk 630090, Russia

Tel.: +7(383)3638036; e-mail: NovikovDA@ipgg.sbras.ru 